\title{
Teorias sobre as Etapas do Capitalismo: Elementos para uma Síntese
}

Theories on the Stages of Capitalism: Elements for a Synthesis

\author{
Marcelo Soares Bandeira de Mello Filho ${ }^{\mathrm{a}}$
}

\begin{abstract}
Resumo: As teorias sobre as etapas do capitalismo investigadas no presente artigo - teorias do imperialismo, teorias do capitalismo monopolista, escola francesa da regulação, escola das estruturas sociais de acumulação e abordagem neoschumpeteriana - analisam as diferentes formas do capitalismo ao longo da história. As insuficiências teóricas apresentadas pelas abordagens derivam, de modo geral, da dificuldade em articular as características mais fundamentais do modo de produção, as estruturas multisseculares do capitalismo, com as estruturas específicas a determinados períodos históricos. Para solucionar tal deficiência e procurar aprofundar a compreensão do neoliberalismo é proposta uma análise do capitalismo baseada nas múltiplas escalas de tempo.
\end{abstract}

Palavras-chave: Etapas do Capitalismo; Imperialismo; Era de Ouro do Capitalismo. Neoliberalismo.

Classificação JEL: B24; B51; B52

\begin{abstract}
The theories of capitalist stages studied in this paper - theories of imperialism, theories of monopoly capitalism, French regulation school, social structures of accumulation approach and neoschumpeterian approach - analyse the different forms of capitalism throughout history. In general, the theoretical problems associated to the theories of capitalist stages are caused by the lack of articulation of the most fundamental characteristics of the mode of production, the multi-secular structures of capitalism, with the structures specific to certain historical periods. To overcome these theoretical problems and search for a deeper understanding of neoliberalism is proposed an analyse the capitalism using multiple time scales.
\end{abstract}

Keywords: Stages of Capitalism. Imperialism. Golden Age of Capitalism. Neoliberalism.

\footnotetext{
a Professor Adjunto da Universidade Federal de São João del-Rei (UFSJ), São João del-Rei, MG, Brasil. E-mail: marcelosbmf@gmail.com.

O presente artigo foi desenvolvido a partir da tese de doutorado do autor (Mello Filho, 2016), defendida no Cedeplar/UFMG, em 2016. A tese foi beneficiada pelos comentários de Carlos Eduardo Suprinyak, Eduardo da Motta e Albuquerque, Eleutério Prado, David Dequech e pela orientação de Hugo Eduardo Araujo da Gama Cerqueira. O trabalho também foi beneficiado pelos comentários do parecerista anônimo. Nenhum dos citados possui responsabilidade pelos equívocos presentes no artigo.
} 


\section{Introdução}

A compreensão das diferentes formas de funcionamento das economias capitalistas ao longo da história é o objeto principal de estudo das teorias sobre as etapas do capitalismo. Diversos autores, na virada do século XX, procuraram atualizar a teoria econômica e a crítica da economia política com o intuito de compreender as mudanças econômicas da época, tais como a mecanização, o surgimento de grandes firmas com poder de mercado (chamadas genericamente de monopólios), o acirramento do nacionalismo e do expansionismo. As teorias acerca do imperialismo e do capitalismo monopolista, analisadas na próxima seção, enfatizam o surgimento de monopólios, do capitalismo financeiro e de grandes montantes excedentes de capital como as causas econômicas do imperialismo.

Entre as décadas de 1940 e 1960, as análises sobre as etapas do capitalismo foram eclipsadas pelo sucesso do keynesianismo em evitar grandes crises e promover elevado crescimento. Contudo, a partir do final da década de 1970, ocorreu um novo tipo de crise econômica nos países centrais, caracterizada como crise de estagflação, que marcou o declínio das políticas keynesianas de crescimento. Esse tipo de crise estimulou a retomada de reflexões acerca das mudanças qualitativas do capitalismo. Surgiram abordagens como a escola francesa da regulação, a escola das estruturas sociais de acumulação e a abordagem neoschumpeteriana, apresentadas na terceira parte deste artigo. As três abordagens compreendem o capitalismo como um sistema econômico que não é autorregulado, mas organizado com base em instituições (que podem ser leis, rotinas, hábitos, costumes etc.), que não são explicáveis apenas pelo cálculo econômico, pois são constructos sociais permeados por elementos políticos, culturais e ideológicos. A construção, o apogeu e a crise das etapas e dos tipos de capitalismo são explicados, respectivamente, pela implantação, pelo pleno funcionamento e pela decadência das estruturas institucionais em dados contextos tecnológicos e organizacionais.

Após apresentar, nas duas próximas seções, as principais teorias sobre as etapas do capitalismo, estas são criticadas na quarta parte deste artigo por apresentarem dificuldade em explicar períodos históricos diversos daqueles em que foram criadas. Desse modo, as teorias do imperialismo e do capitalismo monopolista não conseguiram explicar o capitalismo do pós-guerra. E as teorias que nasceram no ocaso da "era de ouro" do capitalismo apresentam dificuldades para compreender tanto o imperialismo quanto o capitalismo neoliberal. As insuficiências teóricas apresentadas pelas abordagens derivam, de modo geral, da dificuldade em articular as características mais fundamentais do modo de produção, as estruturas multisseculares do capitalismo, com as estruturas específicas a determinados períodos históricos. Na penúltima parte do artigo, procura-se conciliar esses dois conjuntos de estruturas destacando as diferentes escalas de tempo presentes tanto na sociedade, quanto na natureza. Na última seção são apresentados elementos básicos para a compreensão das transformações do capitalismo das últimas décadas. Portanto, não se pretende descartar as teorias sobre as etapas do capitalismo, mas sim estabelecer bases mais sólidas para que seja possível articulá-las melhor com uma teoria sobre as características gerais do modo de produção capitalista. Por fim, na última parte, são traçadas considerações finais. 


\section{Teorias do Imperialismo e do Capitalismo Monopolista}

O objetivo desta seção é analisar os desenvolvimentos das teorias do imperialismo e do capitalismo monopolista, a partir do ponto de vista da conceitualização das etapas do capitalismo. Naturalmente, um tema tão discutido como o imperialismo não poderá ser exaurido aqui. Os conceitos de imperialismo e de capitalismo monopolista foram desenvolvidos por Hobson, Veblen, Lênin, Hilferding, Luxemburgo, Bukharin, Baran, Schumpeter, Sweezy e outros autores, visando compreender as transformações do capitalismo iniciadas no final do século XIX.

A necessidade de compreensão das particularidades da vida econômica no final do século XIX levou autores da época a não mais acreditar que a economia política clássica ou as concepções marginalistas (que enfatizavam o caráter auto-organizador do capitalismo liberal) seriam capazes de apreender a realidade do sistema econômico. Do ponto de vista marxista, um importante desafio era compreender as razões pelas quais, apesar da grande instabilidade econômica ocorrida entre as décadas de 1870 e 1890 e apesar do grande crescimento dos movimentos operários no período, não houve uma revolução socialista e tampouco uma grande crise do capitalismo. A explicação para as transformações pelas quais passava o modo de produção se centrou na monopolização do capital, nas inovações técnicas e organizacionais e no expansionismo imperialista.

$\mathrm{O}$ primeiro grande autor a conceituar com rigor o imperialismo foi Hobson, em livro publicado em 1902. O autor foi inspirado pelo contexto da Guerra dos Bôers onde hoje é a África do Sul -, que presenciou na condição de jornalista. Segundo o autor, o imperialismo se refere ao controle político despótico exercido por uma minoria sobre uma população estrangeira (HOBSON, 1902, p. 7-9). A definição de Hobson, portanto, não restringe o imperialismo a um fenômeno exclusivo do capitalismo.

No capítulo VI de seu livro, Hobson procura pela raiz econômica profunda do fenômeno. A concorrência que os produtos manufaturados da Inglaterra passaram a sofrer, nas últimas décadas do século XIX, por parte da Alemanha, da Bélgica e dos Estados Unidos, fizeram com que a principal potência mundial de então perdesse mercados. Com a busca, pela Inglaterra, da conquista por mercados, outros países, como os EUA e a Alemanha, também começariam a se dedicar ao imperialismo. A influência que os grandes capitalistas têm no mundo político seria responsável pela institucionalização do imperialismo como prática de Estado. De acordo com o autor, existe superprodução, ou excesso de poupança, porque a distribuição de renda não segue a capacidade produtiva da sociedade. Caso os salários aumentassem na proporção da produtividade, não haveria subconsumo (HOBSON, 1902, p. 53-59; 201-202). Portanto, o imperialismo não é uma necessidade do capitalismo. Ele pode ser totalmente superado se o sistema econômico passar por uma "reforma social", que inclua aumentos salariais e de impostos, canalizando a renda para que os trabalhadores e o governo gastem, evitando a superprodução e o desemprego: 
A disputa por mercados, a maior ansiedade dos produtores para vender do que dos consumidores para comprar, é a prova suprema de uma falsa economia da distribuição. $\mathrm{O}$ imperialismo é o fruto dessa falsa economia; a "reforma social" é o remédio. O objetivo primeiro da "reforma social", usando o termo no seu significado econômico, é a ampliação do padrão saudável do consumo privado e público de uma nação, de modo a permitir que a nação viva no mais alto padrão possível de produção (HOBSON, 1902, p. 61, tradução nossa).

O imperialismo foi a principal linha de pesquisa dos autores marxistas das primeiras décadas do século XX. Hilferding (1910), Lênin (1917), Luxemburgo (1913), Bukharin (1917) e outros pensadores marxistas procuraram investigar o fenômeno. De acordo com Hilferding, o novo tipo de capitalismo seria caracterizado, por um lado, pela formação de cartéis e trustes, e, por outro, numa relação cada vez mais intrínseca entre o capital bancário e o capital industrial. É através dessas relações que o capital vai assumir a forma de capital financeiro, sua forma mais elevada e abstrata ${ }^{1}$ (HILFERDING, 1910, p. 27). Por sua vez, Lênin identifica o capitalismo monopolista como o elemento central para a compreensão da etapa do capitalismo:

\begin{abstract}
Se fosse necessário dar uma definição, a mais breve possível do imperialismo, dever-se-ia dizer que o imperialismo é a fase monopolista do capitalismo. Essa definição compreenderia o principal, pois, por um lado, o capital financeiro é o capital bancário de alguns grandes bancos monopolistas fundido com o capital das associações monopolistas de industriais, e, por outro lado, a partilha do mundo é a transição da política colonial que se estende sem obstáculos às regiões ainda não apropriadas por nenhuma potência capitalista para a política colonial de posse monopolista dos territórios do globo já inteiramente repartido (LÊNIN, 1917, p. 217).
\end{abstract}

Uma característica comum aos autores marxistas do início do século XX é a presença de aspectos deterministas. Em algumas passagens de suas obras, vislumbraram o imperialismo como uma fase necessária de transição entre o capitalismo e o socialismo. Nesse sentido, como parte significativa da produção já se encontrava planejada pelos grandes capitalistas e a disputa pelos mercados internacionais leva ao acirramento da luta de classes, esta poderia levar ao socialismo, entendido como o controle social sobre a produção e a distribuição: "O capitalismo, chegado à sua fase imperialista, conduz à socialização integral da produção nos seus mais variados aspectos; arrasta, por assim dizer, os capitalistas, independentemente de sua vontade e sem que disso tenham consciência, para um novo regime social, de transição entre a

\footnotetext{
${ }^{1}$ Hilferding escreveu sua obra principal, "O capital financeiro", em 1905 e a publicou em 1910. O livro procura atualizar e rever algumas das teses de Marx. A obra foi estruturada em cinco partes. A primeira, sobre dinheiro e crédito, inicia com a necessidade do dinheiro nas economias capitalistas e daí deriva a moeda fiduciária, o sistema bancário e o crédito. A segunda parte versa sobre a mobilização do capital, por meio de sociedades anônimas e bolsas de valores, que além de permitirem maior mobilização de capital, favorecem a especulação financeira. A terceira discorre sobre a formação de cartéis, trustes, monopólios (estes são entendidos, como em geral na literatura da época, em um sentido amplo que inclui os oligopólios) e sobre a união entre o capital industrial e o bancário, que formará o capital financeiro, assunto principal da obra e tema da quarta parte do livro. A quinta parte discorre acerca de algumas políticas econômicas associadas ao capital financeiro.
} 
absoluta liberdade de concorrência e a socialização completa" (LÊNIN, 1917, p. 131). $\mathrm{O}$ mesmo tipo de argumento é encontrado em Hilferding ${ }^{2}$ e em Rosa Luxemburgo ${ }^{3}$, embora a obra dessa autora enfatize com maior vigor a conscientização das massas, a luta de classes e a organização democrática dos movimentos revolucionários da classe trabalhadora.

Seguindo os insights de Luxemburgo, Lênin, Bukharin e Hilferding, o conceito de capitalismo monopolista foi desenvolvido principalmente da década de $1960 \mathrm{em}$ diante. O livro Capitalismo monopolista: um ensaio sobre a ordem econômica e social americana, foi publicado por Baran e Sweezy em 1966. Os autores citam Lênin como uma referência teórica, pois ele defendeu que o imperialismo corresponde ao estágio monopolista do capitalismo. Porém, dizem que vão além de Marx, de Lênin e de Hilferding, autores marxistas pioneiros na teorização da formação dos monopólios, ao identificar as "leis de movimento" dessa nova etapa do capitalismo (BARAN, SWEEZY, 1966, p. 4). O foco da investigação é a geração e a absorção do excedente em uma economia com presença importante de grandes firmas com poder de mercado (capacidade de determinar o volume da produção e o nível de preço). Devido à grande concentração de renda nesse tipo de capitalismo, é esperado que este apresente uma tendência à estagnação, apenas compensada por duas contratendências principais: a ocorrência de inovações tecnológicas que marcam época ${ }^{4}$ e a eclosão de guerras. $\mathrm{Na}$ conclusão do livro, Baran e Sweezy (1966, p. 364-367) observam que a revolução socialista estaria se espalhando em vários países, podendo, até mesmo, alcançar os EUA.

A previsão revolucionária não se concretizou. Porém, o conceito de capital monopolista continuou sendo utilizado pelos pensadores influenciados pela Monthly Review. Entre eles, John Bellamy Foster e Fred Magdoff, que publicaram o livro The great financial crisis, em 2009, procurando compreender a crise que teria eclodido no

2 "O capital financeiro na sua perfeição significa o mais alto grau de poder econômico nas mãos da oligarquia capitalista. Ele leva à perfeição a ditadura dos magnatas capitalistas. Simultaneamente, a ditadura dos donos nacionais do capital de um país torna-se cada vez mais incompatível com os interesses capitalistas de outros países, e a dominação do capital dentro do país cada vez mais inconciliável com os interesses dos explorados pelo capital financeiro - mas também com as massas populares chamadas para a luta. No violento choque dos interesses opostos, a ditadura dos magnatas do capital transforma-se finalmente na ditadura do proletariado" (HILFERDING, 1910, p. 346).

3 "O capitalismo é a primeira forma econômica capaz de propagar-se vigorosamente: é uma forma que tende a estender-se por todo o globo terrestre e a eliminar todas as demais formas econômicas, não tolerando nenhuma outra ao seu lado. Mas é também a primeira que não pode existir só, sem outras formas econômicas de que alimentar-se; que tendendo a impor-se como forma universal, sucumbe por sua própria incapacidade intrínseca de existir como força de produção universal. O capitalismo é, em si, uma contradição histórica viva; seu movimento de acumulação expressa a contínua resolução e, simultaneamente, a potencialização dessa contradição. A certa altura do desenvolvimento essa contradição só poderá ser resolvida pela aplicação dos princípios do socialismo [...]" (LUXEMBURGO, 1913, p. 98).

${ }^{4}$ De acordo com os autores, somente três inovações marcaram época: o motor a vapor, a ferrovia e o automóvel. Outras invenções radicais, como a eletricidade e o avião, por exemplo, não teriam respondido por uma mudança tão grande no volume de capital mobilizado, nem teriam provocado transformações cumulativas na geografia econômica como as três anteriormente destacadas (BARAN, SWEEZY, 1966, p. 218-222). 
ano de 2007. O argumento principal do livro é o de que no capitalismo monopolista, com preços fixados pelas principais empresas, há uma tendência de geração de um enorme excedente que não será absorvido pelo consumo, pelo investimento, nem mesmo pelos gastos civis do governo, que são combatidos pelos grupos monopolistas. O sistema só conseguiria se manter graças a artifícios como os elevados gastos militares e a especulação financeira. Esta, inclusive, teria ficado cada vez mais importante como fonte de lucros, alimentando o endividamento das famílias e do próprio governo, que passa a ter de salvar periodicamente o sistema financeiro. E, como consequência lógica do argumento, percebe-se que o problema real da crise contemporânea se encontra no capitalismo monopolista e não na financeirização, que seria apenas um sintoma de um problema mais grave. Para os autores, uma solução real para a crise seria a reconstrução da economia americana com base nos desejos populares, ou seja, a construção do socialismo (FOSTER, MAGDOFF, 2009, p. 22-23).

\section{Teorias Sobre a "Era de Ouro" do Capitalismo}

Na década de 1970 os debates acerca das etapas do capitalismo ganharam novo ímpeto, devido às turbulências que atingiam os principais países capitalistas. As ondas de protestos dos movimentos pacifista, feminista, negro e estudantil (especialmente a partir de 1968), a Guerra do Vietnã, a estagflação, o rompimento do acordo de Bretton Woods (em 1971) e as crises do petróleo de 1973 e 1979 são apenas algumas dessas turbulências.

Entre meados da década de 1970 e o início da década de 1980, algumas escolas de pensamento surgiram, procurando compreender justamente como se construiu e como entrou em crise o padrão de capitalismo do pós-guerra, considerado "a era de ouro" do capitalismo. Três abordagens se destacam: a escola francesa da regulação, a abordagem neoschumpeteriana e a escola das estruturas sociais de acumulação. Estas três escolas têm em comum a rejeição das teorias do imperialismo e do capitalismo monopolista e a ênfase na tecnologia e nas instituições - entendidas de maneira ampla como leis, rotinas, comportamentos tácitos e codificados - enquanto unidades principais de análise para a compreensão dos diferentes tipos de capitalismo. A construção e a decadência das estruturas institucionais marcam cada etapa do capitalismo.

A mais conhecida dessas três abordagens, a escola francesa da regulação, foi sistematizada pela primeira vez no livro Régulation et crises du capitalisme, publicado na França em 1976 e nos Estados Unidos em 1979, baseado na tese de doutorado de Michel Aglietta, defendida em 1974. Além de Aglietta, outros importantes autores ligados à corrente são Boyer, Lipietz e Coriat.

Em 1986, Boyer publicou um livro, lançado em português em 1990, Teoria da regulação: uma análise crítica, que apresenta a abordagem. A passagem a seguir sintetiza bem o projeto teórico da escola, que procura utilizar a história de longa duração 
para criar uma hierarquia de conceitos partindo de $\operatorname{Marx}^{5}$ e utilizar tais conceitos para a compreensão tanto das leis gerais quanto das regularidades históricas do capitalismo:

\begin{abstract}
O objetivo da análise em termos de regulação é, justamente, o de fazer da história de longa duração o meio para um enriquecimento e uma elaboração crítica das intuições marxistas referentes à dinâmica das economias capitalistas. Se ainda é estimulante partir dos ensinamentos de Marx, esta década de pesquisas procurou, precisamente, criar uma hierarquização desta herança: entre os conceitos mais abstratos [...] e as noções que podem e devem ser confrontadas com as evoluções observadas [...]; entre uma relação social geral e as formas específicas que ela assume ao longo do tempo; entre as leis trans-históricas e as simples regularidades econômicas válidas para um conjunto bem específico de formas sociais (BOYER, 1990, p. 65).
\end{abstract}

Considerando que a investigação de Marx acerca do modo de produção capitalista constitua o nível mais abstrato de investigação, o conceito de regime de acumulação, que se refere às regularidades macroeconômicas, estaria em um nível intermediário de abstração. No plano menos abstrato de análise estaria o conceito de modo de regulação, o conjunto das formas institucionais que, por sua vez, são as formas históricas nas quais aparecem as relações sociais básicas do modo de produção. Tal conjunto de conceitos permite que se estabeleça uma periodização do modo de produção. Também possibilita o reconhecimento da diferenciação espacial do capitalismo (LIPIETZ, 1988, p. 45-50; BOYER, 1990; 2004; 2015).

De modo geral, a escola da regulação reconhece dois regimes de acumulação. No regime de acumulação extensiva prevalece a extração de mais-valia absoluta (é um regime de baixo crescimento da produtividade), enquanto na acumulação intensiva prevalece a extração de mais-valia relativa (ou seja, elevado crescimento da produtividade).

O fordismo, padrão de crescimento dos países desenvolvidos durante a "era de ouro" do capitalismo (1945-1973), seria entendido a partir da conjunção de um regime de acumulação intensiva com um modo de regulação monopolista:

Após a Segunda Guerra Mundial, o regime de acumulação intensiva, centrado no consumo em massa, pôde se generalizar justamente porque um novo modo de regulação, monopolista, havia incorporado a priori na determinação dos salários e dos lucros nominais, um crescimento do consumo popular em proporção aos ganhos de produtividade (LIPIETZ, 1988, p. 50).

No âmbito do modo de regulação, as principais instituições seriam: 1) relação salarial marcada por convênios coletivos, salário mínimo crescente, previdência social

\footnotetext{
${ }^{5}$ Em textos mais recentes, Boyer reafirma que a escola se inscreve na tradição do pensamento de Marx, "mas pretende alterar e prolongar a análise de 'O capital', tanto à luz dos métodos modernos dos economistas quanto graças aos ensinamentos derivados das transformações do capitalismo desde o final do século XIX". Entretanto, o autor critica tanto Marx quanto os teóricos do imperialismo e do capitalismo monopolista de Estado por enfatizarem principalmente a queda da taxa de lucro como causa das crises e por terem subestimado a capacidade de mudança qualitativa do modo de produção capitalista (BOYER, 2004, p. 33-36; 2015, p. 40-43).
} 
e outras formas de salário indireto; 2) gestão da moeda marcada pelo dinheiro fiduciário e pela generalização dos empréstimos bancários para as firmas e famílias; 3) formas de governo do tipo Estado-Providência e que adotam políticas keynesianas; 4) hegemonia americana, no plano internacional (LIPIETZ, 1988, p. 52-56).

Por sua vez, a crise do fordismo teria começado com uma desaceleração geral dos ganhos de produtividade. Em seguida, teria ocorrido uma compressão dos lucros (profit squeeze) decorrente dos aumentos salariais e responsável tanto pelo crescimento inflacionário, quanto por menores níveis de investimento e de emprego (AGLIETTA, 1976; LIPIETZ, 1988; BOYER, 1998; CORIAT, 1994). Segundo os autores regulacionistas, as décadas de 1980 e 1990 são marcadas pela busca de novos regimes de crescimento (chamados de pós-fordistas) (BOYER, SAILLARD, 2002). Mais recentemente, no início dos anos 2000, os regulacionistas identificaram o regime de acumulação liderado pelas finanças como o regime que estaria prevalecendo nos Estados Unidos (BOYER, 2004; 2015). Após o estouro da bolha das hipotecas subprime, os autores regulacionistas se voltaram ao aprofundamento da compreensão do padrão de crescimento americano das últimas décadas e adotaram a visão de que se tratava de um regime de acumulação caracterizado como "liderado pelas finanças" (BOYER, 2011) ou "liberal-produtivista" (LIPIETZ, 2012; 2015). Tal modelo, entretanto, já teria colapsado. Um novo modo de desenvolvimento poderia, então, emergir.

A abordagem evolucionária neoschumpeteriana surgiu entre o final da década de 1970 e o início da década de 1980, procurando teorizar o surgimento e a difusão de inovações e de conhecimento na economia, assim como as transformações técnicas e organizacionais que originam diferentes ondas de progresso técnico e de crescimento econômico. Seguindo as contribuições de Schumpeter, a inovação é considerada o principal elemento analítico do capitalismo, responsável pela sua dinâmica. Entre os principais autores neoschumpeterianos, pode-se destacar Richard Nelson, Sidney Winter, Carlota Perez, Chris Freeman, Giovanni Dosi e Francisco Louçã. Algumas das principais linhas de pesquisa desenvolvidas pela abordagem neoschumpeteriana são a construção de uma teoria evolucionária das firmas e dos mercados (NELSON, WINTER, 1982) e a investigação da interação entre firmas e instituições de ensino e pesquisa formando sistemas de inovação (LUNDVALL, 2007; FREEMAN, 2002). Outra linha de pesquisa, investigada neste artigo, procura compreender mudanças de longo prazo do capitalismo. As obras neoschumpeterianas acerca das ondas longas do capitalismo (PEREZ, 1983, 2012; LOUÇÃ, 2007; FREEMAN, LOUÇÃ, 2004) advogam na história econômica do capitalismo a alternância entre longos períodos de rápido crescimento econômico e outros longos períodos de crise ou estagnação, liderados pelo surgimento e difusão de paradigmas tecnológicos e de regimes de regulação (ou regimes socioinstitucionais). Tais ondas longas são também conhecidas como ciclos de Kondratiev.

Uma fase ascendente de uma onda longa, uma "era de ouro", ocorre quando há uma complementaridade harmônica entre os padrões tecnológico e socioinstitucional, o 
que acelera a difusão e generalização do padrão tecnológico. Quando a tecnologia se aproxima de seus limites de lucratividade, as empresas começam a investir menos recursos na produção e mais na especulação, formando as bolhas características das "eras douradas" (gilded ages) (PEREZ, 1983, 2012). Enquanto as novas tecnologias começam a ser implantadas, a insatisfação da sociedade estimula mudanças sociais, políticas e institucionais. Segundo os defensores de tal abordagem, a tecnologia é um elemento fundamental para a explicação das mudanças históricas do capitalismo, mas a política e a cultura também são fundamentais (FREEMAN, LOUÇÃ, 2004, p. 378).

Carlota Perez (2012) identifica duas ondas longas no século $\mathrm{XX}^{6}$. Uma onda longa que vai de 1908 até 1971, é considerada a quarta onda longa do capitalismo. As principais inovações da época foram o automóvel, a aviação, a eletricidade, o rádio e outros produtos de fabricação em massa. Ainda segundo Perez (2012), uma nova onda longa está ocorrendo desde 1971, graças às tecnologias de comunicação e informação. Porém, não foram ainda construídas instituições que permitam que a "era dourada" seja substituída pela "era de ouro", que tem que ser sustentável em termos sociais e ambientais, combinando tecnologias de informação e comunicação (TIC) com crescimento "verde".

Assim como os autores neoschumpeterianos, as primeiras pesquisas que deram origem à abordagem das estruturas sociais de acumulação enfatizavam as ondas longas do capitalismo (GORDON, 1978). Com o passar do tempo, a ênfase nas ondas longas foi substituída pela tentativa de combinar as contribuições teóricas de Marx com uma análise menos abstrata das instituições e dos tipos de crise característicos dos diferentes períodos do capitalismo. Embora considerem importantes as tendências delineadas por Marx, os autores da escola - Gordon, Bowles, Reich, Edwards, Kotz, McDonough, etc - defendem que tais tendências estão estabelecidas em um nível ainda muito abstrato. Não se pode compreender o que ocorre com o sistema capitalista apenas a partir delas. Para alcançar tal compreensão seria necessária a construção de um nível intermediário de análise, chamado de estrutura social de acumulação, que não se resume nem ao estrato mais abstrato de pensamento, nem ao nível factual dos estudos de caso:

\begin{abstract}
Nós propomos que um nível intermediário de análise, focado na lógica das ondas longas e das etapas do capitalismo, é necessário para a compreensão do desenvolvimento capitalista. Esse nível de análise intermediário procura complementar tanto a análise abstrata e tradicional de Marx do desenvolvimento capitalista quanto a análise mais recente e concreta da vida cotidiana (GORDON, EDWARDS, REICH, 1982, p. 22, tradução nossa).
\end{abstract}

Os autores identificam quatro pilares do arcabouço institucional do pós-guerra: 1) a pax americana, o poder militar e econômico dos Estados Unidos; 2) o acordo

\footnotetext{
${ }^{6}$ De acordo com Freeman (2000), ocorreram cinco ondas longas no capitalismo. A primeira onda aconteceu entre 1780 e 1840, impulsionada pela indústria têxtil, a segunda onda ocorreu entre 1840 e 1890, tendo como principal inovação o motor a vapor (e com esse as ferrovias), a terceira onda durou de 1890 a 1940 , puxada pela eletricidade e pela química pesada, a quarta onda durou de 1940 a 1990, impulsionada pelo automóvel, pelos bens de consumo duráveis e pelos materiais sintéticos. Finalmente, a quinta onda de Kondratiev iniciou-se nos anos 1990, impulsionada pela informática e pelas telecomunicações.
} 
capital-trabalho, que permitia ganhos salariais reais dos trabalhadores em troca de controle absoluto sobre a produção; 3) o acordo entre capitalistas e cidadãos, que permitia ao Estado reduzir a instabilidade macroeconômica e promover gastos públicos em infraestrutura, defesa, saúde, educação e seguridade social; 4) contenção da rivalidade intercapitalista, resultado de mercados oligopolizados (BOWLES, GORDON, WEISSKOPF, 1984; 1990).

Já a partir de meados da década de 1960, as fundações desse sistema teriam começado a erodir. No plano internacional, as empresas europeias e japonesas estavam mais competitivas, erodindo os superávits comerciais americanos. Além disso, os Estados Unidos são derrotados no Vietnã e a Opep aumenta o preço do petróleo. No que se refere ao acordo capital-trabalho, a coalizão que possibilitava crescimento econômico e salários crescentes passou a ser ameaçada. Estava crescendo a insatisfação dos excluídos da relação salarial, principalmente negros e mulheres. Os déficits fiscais crescentes, aliados a uma política monetária expansionista em um ambiente de baixa taxa de desemprego e salários reais crescentes, contribuiriam com a pressão inflacionária e com a diminuição dos lucros (BOWLES, GORDON \&WEISSKOPF, 1984; 1990).

Assim como os autores da escola da regulação, os adeptos da abordagem em termos de estruturas sociais de acumulação compreendiam o capitalismo das décadas de 1980 e 1990 como uma continuação da crise dos anos 1970. Se a agenda neoliberal estava sendo bem-sucedida em reduzir o papel do Estado, ela não estaria sendo capaz de construir uma estrutura social de acumulação, "um conjunto de instituições que promovem uma acumulação rápida e estável". A superação de tal crise só seria possível com a criação de uma nova estrutura social de acumulação:

[...] se uma estrutura social de acumulação é entendida não apenas como um conjunto de instituições que afeta a acumulação de capital, mas como um conjunto de instituições que promovem uma acumulação rápida e estável, então a continuação da ausência de rápido crescimento no longo prazo dos países capitalistas industrializados é inconsistente com o argumento de que nós temos agora uma estrutura social de acumulação neoliberal (KOTZ, 2001, p. 97, tradução nossa).

Entretanto, mais recentemente, os autores da escola começaram a teorizar o capitalismo das últimas décadas como sendo algo mais do que uma simples continuação da crise da década de 1970. David Kotz foi o principal teórico a advogar essa ruptura, que promove uma releitura do conceito central da escola. Como o neoliberalismo é uma estrutura institucional coerente que existe desde os anos 1980, ele é uma estrutura social de acumulação, apesar de promover um baixo crescimento econômico (WOLFSON, KOTZ, 2010, p. 73). Não há argumentos teóricos sólidos para justificar que uma estrutura social de acumulação tenha que promover o crescimento econômico acelerado; o simples fato de que um período de elevado crescimento exija uma estrutura social de acumulação adequada não implica que toda estrutura social de acumulação garanta rápido crescimento (WOLFSON, KOTZ, 2010, p. 76-77).

Depois da crise iniciada em 2008, vários dos desenvolvedores da abordagem das 
estruturas sociais de acumulação (KOTZ, MCDONOUGH, 2010; LIPPIT, 2013) afirmaram que a crise marca o colapso da estrutura social de acumulação neoliberal, que não poderia ser reformada de maneira modesta:

\begin{abstract}
As falas sobre a reestruturação econômica estão por toda parte na época em que estamos escrevendo. A teoria da estrutura social de acumulação não pode prever a direção que a reestruturação econômica vai tomar. Entretanto, a teoria da estrutura social de acumulação sugere que sustentar a estrutura social de acumulação neoliberal global não é uma opção viável e que, nos próximos anos, vai emergir um novo caminho para o sistema global, originado das lutas de várias classes e grupos (KOTZ, MCDONOUGH, 2010, p. 118, tradução nossa).
\end{abstract}

\title{
4. Insuficiências Teóricas das Abordagens Analisadas
}

As teorias do imperialismo e do capitalismo monopolista, historicamente, mostraram-se uma importante fonte de insights para o entendimento do capitalismo predominante na primeira metade do século XX. As teorias sobre as "eras de ouro" foram bem-sucedidas na explicação do período de crescimento econômico mais acelerado da história, entre o pós-guerra e a década de 1970. A despeito do sucesso em explicar etapas específicas do capitalismo, as abordagens falharam em um objetivo mais amplo: a explicação para etapas diferentes daquelas em que as teorias foram elaboradas. Os diferentes autores se apegaram a um aspecto histórico ou teórico específico e analisaram o capitalismo como um todo desse ponto de vista, parcial e enviesado.

Desse modo, as transformações históricas do capitalismo eram explicadas de modo reducionista. Por exemplo, Hobson compreende o imperialismo como resultado da tendência ao subconsumo. Mais recentemente, Baran e Sweezy adotaram um ponto de vista análogo, estagnacionista, que tem pouca capacidade de explicar as elevadas taxas de crescimento das décadas de 1950 a 1970. Voltando aos autores das primeiras décadas do século passado, Hilferding, Bukharin e Lênin explicam as mudanças nas etapas do capitalismo com base em transformações no plano da esfera da concorrência, que teriam dado origem ao capitalismo monopolista.

A maior parte dos teóricos do imperialismo e do capitalismo monopolista viam essas etapas do capitalismo como as formas mais avançadas desse, que tenderia a entrar em crise e dar lugar ao socialismo. O maior nível de coordenação entre as empresas monopolistas e a maior atuação estatal seriam formas intermediárias de organização de uma economia que se direcionaria ao socialismo. Na prática, a história não caminhou nesse sentido linear e o capitalismo mostrou uma grande capacidade de se reinventar. Somente Hobson, autor pioneiro na conceitualização do imperialismo e do capitalismo monopolista, considerou a possibilidade das lutas dos trabalhadores e dos socialistas em geral modificarem a ação do Estado nas economias capitalistas e promoverem o aumento da parcela dos salários na renda nacional. Paradoxalmente, os autores marxistas do imperialismo e a corrente inspirada pelo trabalho de Baran e Sweezy subestimam a capacidade de os trabalhadores influenciarem as políticas estatais dentro do modo de produção capitalista. 
De modo bastante geral, é necessário sublinhar que as teorias do imperialismo e do capitalismo monopolista, por um lado, apresentam contribuições duradouras para o entendimento do capitalismo, como os conceitos de capital financeiro e de capitalismo monopolista, a análise da exportação de capital, da concentração de capital e da distribuição de renda, assim como a investigação da relação promíscua entre grandes corporações e o Estado. Alguns desses aspectos estiveram presentes desde o início do capitalismo, por exemplo nas políticas mercantilistas, colonialistas e de dívida pública, destacadas por Marx no contexto da acumulação primitiva de capital e são uma tendência presente no capitalismo de modo geral (GROSSMAN, 1929; HARVEY, 2003).

Por outro lado, é importante deixar claro uma grande limitação dos autores do imperialismo e do capitalismo monopolista: os conceitos que dão nome às abordagens se enquadram bem às grandes potências do final do século XIX e início do século XX e ao capitalismo americano atual, mas não à totalidade da Europa Ocidental e do Japão desde o fim da Segunda Guerra Mundial. Nessas últimas regiões não foi necessário recorrer a elevados gastos militares e ao endividamento das famílias para sustentar a demanda. Portanto, contrariando as previsões da maior parte dos teóricos do imperialismo e do capitalismo monopolista, com a importante exceção de Hobson, os trabalhadores conseguiram elevados ganhos de salário real mesmo em países com estruturas concorrenciais tão ou mais concentradas que a estadunidense.

A existência de monopólios e oligopólios não implica em um tipo único de política de Estado. Do ponto de vista de uma teorização das etapas do capitalismo, outros critérios (além do tipo de empresa prevalecente), como o tipo de moeda (metálica ou fiduciária), o tipo de relações de trabalho, o padrão de ação econômica do Estado (seja ele liberal, keynesiano, neoliberal, ou desenvolvimentista) e o tipo específico de ambiente internacional, são necessários para a compreensão das etapas do capitalismo, como os autores da escola da regulação, da abordagem das estruturas sociais de acumulação e da escola neoschumpeteriana observaram. Entretanto, essas três abordagens também apresentaram sérios problemas teóricos e análises históricas insuficientes.

De acordo com a escola da regulação, a Grande Depressão teria sido causada pela aceleração dos ganhos de produtividade (oriunda da generalização das técnicas fordistas) não acompanhada pela elevação proporcional dos salários. Clarke (1991) questiona a existência de um regime de acumulação extensiva: "[a] ideia de que a acumulação antes da Primeira Guerra Mundial era baseada na produção de mais-valor absoluto parece muito estranha para alguém familiarizado como os rudimentos da história econômica do capitalismo" (CLARKE, 1991, p. 113, tradução nossa). Brenner (1999, p. 61-63) critica a concepção regulacionista de que a capacidade declinante - e exógena à economia - de desenvolver a produtividade causou a crise do fordismo. E classifica, de modo provocativo, esse tipo de concepção de "malthusiana".

Uma importante insuficiência teórica das três correntes surgidas nos anos 1970 é a incapacidade de compreensão do capitalismo das últimas décadas. Os autores das 
escolas compreenderam as décadas de 1980, 1990 e mesmo os primeiros anos do novo milênio como períodos de continuidade da crise dos anos 1970. Coutrot (2009, p. 261) é um dos autores que reconhece a falha dos regulacionistas e da escola das estruturas sociais de acumulação em identificar nas experiências neoliberais uma alternativa viável a longo prazo para o capitalismo:

(...) assim como os regulacionistas franceses, os radicais subestimaram consideravelmente a coerência e efetividade da contrarrevolução de Reagan. Custou-lhes um longo tempo para entender que o neoliberalismo poderia gerar novas estruturas sociais para a acumulação capitalista, que seriam certamente menos homogeneizadoras e menos igualitárias que aquelas do período do pós-guerra, mas, no entanto, capazes de restaurar a lucratividade do investimento de forma duradoura (COUTROT, 2009, p. 261, tradução nossa).

Os teóricos regulacionistas, das estruturas sociais de acumulação e neoschumpeterianos passaram algumas décadas procurando compromissos que serviriam de base para novas "eras de ouro" do capitalismo. Mas, segundo alguns críticos, a própria forma compromisso ou acordo entre classes não é mais a forma típica de construção de instituições: "Nos últimos vinte anos o capital agiu de maneira coerente não só para reverter a seu proveito o conteúdo dos compromissos, mas também para eliminar a figura mesma do compromisso, a forma contrato. $\mathrm{O}$ mercado contra o contrato, o individualismo contra todo sujeito coletivo e solidário, o liberalismo contra o Estado de bem-estar" (NEGRI, 1994, p. 3, tradução nossa).

Uma importante crítica foi elaborada por Stavros Mavroudeas (2006), que critica os regulacionistas e a escola das estruturas sociais de acumulação por terem se afastado de uma "teoria geral abstrata" do capitalismo e adotado um "tipo de análise intermediária". As análises intermediárias procurariam se basear em fatos estilizados e explicá-los. Por isso seriam populares durante o período histórico no qual os fatos estilizados são relevantes. Entretanto, uma vez que ocorra uma mudança no capitalismo, as questões mais fundamentais voltariam a ser destacadas e as teorias intermediárias perderiam capacidade explicativa.

O diagnóstico aqui realizado contraria a concepção de que as escolas analisadas ao longo deste artigo abandonaram uma visão geral do capitalismo e aponta que, quando tentaram fazê-lo, acabaram adotando, seja de modo explícito, seja implícito, uma compreensão do modo de produção capitalista inadequada e inconsistente com o projeto inicial das escolas. É por isso que os autores do imperialismo e do capitalismo monopolista viam os monopólios como uma transformação que levaria ao socialismo; que os autores da escola das estruturas sociais de acumulação aceitaram, sem nenhuma justificativa teórica adequada, que uma estrutura social de acumulação seria um arcabouço institucional que permitiria "estabilidade econômica" e "crescimento relativamente rápido" (KOTZ, MCDONOUGH, REICH, 1994b, p. I); que os regulacionistas procuram, há décadas, por novos "compromissos institucionalizados" (BOYER, 2015) ou que os neoschumpeterianos argumentam que ocorrerão novas "eras de ouro" (PEREZ, 2012). A superação de tais equívocos acerca das características gerais do capitalismo passa pela retomada dos projetos teóricos originais de conjugar uma 
análise mais geral e abstrata das relações sociais com as formas históricas que essas relações assumem (BOYER, 1990, p. 65; GORDON, EDWARDS, REICH, 1982, p. 22).

A maneira mais adequada de evitar que características idiossincráticas a uma fase específica do capitalismo sejam generalizadas equivocadamente a todas as etapas do capitalismo é elaborando uma teoria estratificada do modo de produção capitalista. Tal teoria pode ter início com o resgate, ainda que de maneira necessariamente não exaustiva, de um plano mais básico de análise, das características presentes no capitalismo em geral (nas suas diversas fases). O próprio estabelecimento desse nível básico de investigação demonstra a necessidade da investigação de diferentes tipos de capitalismo.

\section{Elementos para uma Teoria Estratificada das Etapas do Capitalismo}

Com o intuito de superar os problemas teóricos e metodológicos apresentados pelas teorias sobre as etapas do capitalismo, será adotada a concepção de que a investigação do capitalismo pode se valer da multiplicidade das escalas de tempo. Tal estratégia não procura descartar as contribuições das teorias aqui analisadas, mas sim que as mesmas sejam, ao mesmo tempo, conservadas e superadas, como pretende a dialética marxista. Desse modo, procura-se preservar os avanços das teorias na compreensão das formas específicas do capitalismo ao mesmo tempo em que são resgatadas contribuições teóricas de outras tradições, especialmente a tradição marxista, para dar conta de articular tanto as características gerais do modo de produção quanto as propriedades específicas a determinados contextos históricos.

Como todas as ciências, as ciências humanas se ocupam de investigar as estruturas e as propriedades do mundo real. O tecido social é formado por uma multiplicidade de relações sociais e por agentes (que ocupam posições sociais). Seguindo a contribuição de Braudel (1992), é importante distinguir e analisar, de maneira articulada, os efeitos das estruturas ${ }^{7}$ de diferente "duração social, esses tempos múltiplos e contraditórios da vida dos homens, que não são apenas a substância do passado, mas também o estofo da vida social atual” (BRAUDEL, 1992, p. 43) ${ }^{8}$.

\footnotetext{
${ }^{7}$ É importante destacar que não são apenas as ciências humanas que reconhecem a existência de diferentes escalas de tempo. Prigogine (1996) centra sua análise na irreversibilidade, a "flecha do tempo", na física. Além disso, reconhece a existência de diferentes escalas de tempo na geologia, na biologia, na química, na física e nas ciências humanas. Wallerstein (1998) argumenta que Prigogine e Braudel desenvolveram, respectivamente, os conceitos de flecha do tempo e de longa duração com o objetivo de descrever a realidade (natural e social) como um caminho intermediário entre o determinismo absoluto e a ausência de ordem e explicação.

${ }^{8}$ A obra de Fernand Braudel (1992) procurou distinguir e analisar várias estruturas com diferentes temporalidades e que implicam em tendências históricas diversas: "Assim chegamos a uma decomposição da história em planos escalonados. Ou, se quisermos, à distinção, no tempo da história, de um tempo geográfico, de um tempo social, de um tempo individual" (BRAUDEL, 1992, p. 15). Entretanto, diferentemente de Braudel, que enfatiza as trocas, o comércio e as finanças, a presente seção prioriza o
} 
É importante ter em mente que, assim como nas ciências naturais, as propriedades e as tendências associadas às relações sociais necessariamente se sobrepõem, combinam-se e se anulam. No caso específico do presente trabalho, que procura analisar diferentes teorias de periodização do capitalismo, é relevante distinguir duas temporalidades principais nas relações sociais: as estruturas de longa duração, ou multisseculares, versus as estruturas específicas, ou de época ${ }^{9}$. Se o intuito da análise for a compreensão mais concreta do funcionamento do capitalismo em um intervalo mais curto de tempo é preciso, ainda, fazer o estudo do âmbito conjuntural, ou factual.

Uma teoria adequada das etapas do capitalismo deveria partir das características mais básicas e gerais do capitalismo, como fez Marx, em "O capital". Depois de estabelecidas as propriedades básicas do capitalismo, pode-se derivar diferentes modalidades possíveis desse, a partir da análise de características históricas e geográficas específicas. Foge ao escopo do presente trabalho exaurir tal teoria, mas alguns elementos podem ser delineados. Na sequência, serão identificadas tendências multisseculares, derivadas da análise de Marx sobre as características fundamentais do modo de produção capitalista. É importante frisar que a análise desenvolvida a seguir não procura exaurir o tema e sim indicar um possível ponto de partida para a conjugação das teorias sobre as etapas do capitalismo com a análise dos elementos duradouros do modo de produção.

Marx (1894, p. 940-944) identifica duas relações sociais centrais do modo de produção capitalista. Em primeiro lugar, a produção social aparece na forma de mercadorias. Isso significa que os bens que as pessoas necessitam para sua reprodução cultural, física e material são obtidos primariamente por meio do mercado. No capitalismo, os produtos do trabalho humano aparecem na forma de riqueza abstrata, quantitativa, a forma valor. Entretanto, a produção não é realizada com o intuito de satisfazer as necessidades das pessoas (o valor de uso) e sim com o objetivo de ampliação dos recursos $\left(\right.$ valor $^{10}$ ) originalmente adiantados pelos proprietários dos meios de produção. A segunda relação social definidora do modo de produção capitalista é que a própria força de trabalho é uma mercadoria. Os trabalhadores apenas terão acesso aos bens necessários para a sua sobrevivência vendendo a própria força de trabalho:

mundo da produção e do trabalho, que serviram de base para a análise de Marx em "O capital".

${ }^{9}$ Entende-se estrutura como relações sociais recorrentes, que ao mesmo tempo possibilitam e restringem a ação humana nas diferentes sociedades: "Por estrutura, os observadores do social entendem uma organização, uma coerência, relações bastante fixas entre realidades e massas sociais [...]. Certas estruturas, por viverem muito tempo, tornam-se elementos estáveis de uma infinidade de gerações: atravancam a história, incomodam-na, portanto, comandam-lhe o escoamento. Outras estão mais prontas a se esfarelar. Mas todas são ao mesmo tempo, sustentáculos e obstáculos" (BRAUDEL, 1992, p. 49-50).

${ }^{10}$ A lei do valor, em Marx, deve ser entendida a partir de diferentes níveis de abstração. Em um primeiro momento, a lei do valor aparece como a tendência à determinação do preço a partir do tempo de trabalho socialmente necessário. Posteriormente a lei do valor aparece como a tendência à estruturação e à reestruturação do mundo do trabalho a partir da redução do tempo de trabalho socialmente necessário. A lei do valor ainda aparece como meio da distribuição do trabalho e do produto social tanto no âmbito nacional quanto no plano internacional (BORGES NETO, 2004). 
Ele [o modo de produção capitalista] produz seus produtos como mercadorias. Produzir mercadorias não o distingue de outros modos de produção, mas sim o fato de que ser mercadoria constitui o caráter dominante e determinante de seu produto. Isso implica, desde já, que o próprio trabalhador só aparece como vendedor de mercadoria e, por isso, como assalariado livre, ou seja, que o trabalho aparece em geral como trabalho assalariado (MARX, 1894, p. 941).

O desenvolvimento histórico e lógico das relações sociais capitalistas engendra diversas leis de movimento, ou tendências, que se manifestam de distintas maneiras ao longo da história econômica mundial. O fato de a vida econômica da sociedade se estruturar em torno da relação capital-trabalho traz algumas importantes características e tendências para o mundo da produção e do trabalho, que não podem ser adequadamente tratadas no presente texto, embora devam ser mencionadas. Antes de explorar tais consequências, é importante mencionar outras características do modo de produção capitalista, derivadas da circulação de mercadorias.

Uma tendência associada à própria lógica da circulação de mercadorias é a definição de alguma mercadoria específica, que se destaca das demais, configurando o dinheiro. O desenvolvimento histórico e lógico da forma dinheiro aponta para a substituição do dinheiro mercadoria tanto pelo crédito quanto por formas fiduciárias da moeda, que prescindem do conteúdo material e do valor agregado. A padronização da moeda em um espaço geográfico é feita por alguma autoridade, algum poder político.

Outra característica derivada da generalização das trocas em uma sociedade é a possibilidade de descompasso entre as decisões individuais dos agentes privados, uma das principais causas das crises. Esse descompasso pode se manifestar tanto em crises de desproporção entre setores quanto de insuficiência de demanda agregada. A possibilidade de retenção de ativos líquidos está na base da crítica de Marx à "lei de Say" e do princípio da demanda efetiva, sistematizado por Keynes e Kalecki. Se, por um lado, uma diminuição abrupta da demanda - ou da realização da produção, nos termos de Marx - provoca crises econômicas, por outro lado, não há necessidade dos níveis de renda, de crescimento e de emprego manterem-se elevados ${ }^{11}$.

\footnotetext{
Ninguém pode vender sem que outro compre. Mas ninguém precisa comprar apenas pelo fato de ele mesmo ter vendido. A circulação rompe as barreiras temporais, locais e individuais da troca de produtos precisamente porque provoca uma cisão na identidade imediata aqui existente entre o dar em troca o próprio produto do trabalho e o receber em troca o produto do trabalho alheio, transformando essa identidade na antítese entre compra e venda. Dizer que esses dois processos independentes e antitéticos formam uma unidade interna significa dizer que sua unidade interna se expressa em antíteses externas. Se, completando-se os dois polos um ao outro, a autonomização externa do internamente dependente avança até certo ponto, a unidade se afirma violentamente por meio de uma crise. A antítese, imanente à mercadoria, entre valor de uso e valor, na forma do trabalho privado que ao mesmo tempo tem de se expressar como trabalho imediatamente social, do
}

\footnotetext{
${ }^{11}$ Essas considerações básicas acerca de uma economia mercantil contradizem a concepção pré-teórica da abordagem da regulação e da escola da estrutura social de acumulação de que o funcionamento normal do capitalismo está necessariamente associado ao elevado crescimento e à estabilidade.
} 
trabalho particular e concreto que ao mesmo tempo é tomado apenas como trabalho geral abstrato, da personificação das coisas e coisificação das pessoas - essa contradição imanente adquire nas antíteses da metamorfose da mercadoria suas formas desenvolvidas de movimento. Por isso, tais formas implicam a possibilidade de crises, mas não mais que sua possibilidade (MARX, 1867, p. 187).

As relações sociais capitalistas aparecem nas mais diversas formas. O capital, essa "unidade movente", é o "sujeito das distintas transformações" (MARX, 1857-1858, p. 518). Ora ele aparece na forma de mercadorias, ora na forma de capital variável e de capital fixo e, à medida que o processo de acumulação de capital avança, aparece nas formas mais etéreas de capital portador de juros e de capital fictício.

O capital portador de juros mistifica as relações sociais capitalistas ao ocultar a transformação de parte do excedente na forma de juros: "O caráter fetichista do capital e a representação do fetiche do capital agora estão completos [...]. [O capital portador de juros é] a mistificação do capital em sua forma mais flagrante" (MARX, 1894, p. 516). O capital fíctício representa "direitos sobre rendimentos" ou "títulos de propriedade" representados num "montante de capital monetário fictício constantemente variável" (MARX, 1894, p. 527). Com o desenvolvimento do capital fictício, este procura se autonomizar totalmente em relação ao capital produtivo. $\mathrm{Na}$ valorização monetária do capital fictício, "[...] toda conexão com o processo real de valorização do capital é apagada até o último rastro, confirmando a ideia de que o capital é automaticamente valorizado por seus próprios poderes" (MARX, 1894, p. 597). A existência do crédito, de títulos de dívida e de ativos baseados na promessa de remuneração futura permite um maior grau de plasticidade ao sistema capitalista, embora amplie as possibilidades de crise.

No capitalismo, o trabalho social é distribuído e realizado por meio do mercado. Uma parte da produção social remunera os trabalhadores, enquanto a outra parte, que Marx chama de mais-valor, é apropriada pelos capitalistas. Trabalhadores e capitalistas disputam a distribuição da produção social. A concorrência entre os capitalistas impele as unidades produtivas a procurarem reduzir os custos de produção e, com isso, diminuir a quantidade de trabalho despendida no processo produtivo. Essa é outra característica do modo de produção capitalista: o aumento da produtividade do trabalho.

Uma das consequências da estruturação da vida material em torno da forma mercantil é a marginalização da produção não voltada ao mercado. Ao diferenciar a "produção dos meios de vida" da "produção da vida", feministas marxistas conseguiram explicar o papel subordinado das mulheres na sociedade capitalista a partir do papel ocupado por elas na produção da vida (gravidez, amamentação e criação de filhos, por exemplo), que gera uma característica importante no capitalismo: a carga excessiva de trabalho doméstico realizado pelas mulheres (com atividades não monetizadas e não reconhecidas pela sociedade) e a dificuldade do seu acesso às posições de destaque no mundo do trabalho submetido às relações sociais capitalistas (HAUG, 2015).

Outra característica básica da estruturação da sociedade em torno do mercado é que as relações sociais entre as pessoas aparecem como propriedades naturais das coisas. Desse modo, o fato de o trabalho social ser distribuído na forma de mercadorias 
é obscurecido. $\mathrm{O}$ fato de as pessoas adquirirem os bens e serviços de que necessitam no mercado, faz com que a forma mercantil seja considerada algo natural e inerente aos objetos, como o peso, a cor e o volume. Quando obtemos produtos no mercado não tomamos conhecimento das condições de trabalho envolvidas na produção e no comércio das mercadorias. Marx chama esse processo de fetichismo da mercadoria. Essa é mais uma propriedade do capitalismo: a mistificação e a naturalização das relações sociais capitalistas.

O fetichismo existe em diversos níveis na sociedade capitalista. Um dos âmbitos no qual ocorre é o fenômeno que Marx chama de "personificação das coisas e coisificação das pessoas", processo complexo associado, por exemplo, à personificação de estruturas sociais, como o mercado - que parece ter uma vontade própria, à qual as pessoas devem se submeter - e associado também à reificação dos trabalhadores, considerados como um mero custo de produção (o capital variável), que pode e deve ser reduzido, ou descartado. A personificação das coisas implica que os problemas da sociedade apareçam como problemas dos indivíduos. Desse modo, problemas como desemprego e criminalidade, por exemplo, aparecem como características inerentes aos desempregados e aos criminosos em vez de características da sociedade. Os agentes políticos muitas vezes optam pela repressão aos indivíduos em vez da reforma da estrutura social que origina o problema, o que reforça a coisificação das pessoas. A coisificação do ser humano no sistema capitalista pode, inclusive, estar associada à guerra e à violência endêmica em várias partes do mundo, uma tendência importante do capitalismo.

O desenvolvimento das forças produtivas do trabalho social se choca com a estreiteza das relações sociais capitalistas. Ocorre uma tensão entre o fato de a produção depender cada vez mais do trabalho passado - que se cristaliza no conjunto de máquinas e equipamentos, mas também no acúmulo de conhecimento científico e tecnológico em detrimento da força de trabalho viva, que ainda precisa ser vendida pela maior parte dos membros da sociedade, para sua própria sobrevivência. Essa característica é uma das formas principais de funcionamento da lei do valor ${ }^{12}$ : a sociedade se estrutura e se reestrutura de diferentes maneiras em torno do trabalho social ${ }^{13}$, que é potencializado, mas não necessariamente é utilizado para satisfação das necessidades humanas (POSTONE, 2014). A mesma pressão concorrencial que impele à criação de novos produtos e ao aumento da produtividade também pressiona para a redução do padrão de vida dos trabalhadores e para a ampliação da jornada de trabalho. Por isso, ocorre uma tendência de grande parte da classe trabalhadora e do exército de reserva não terem acesso aos bens produzidos pela sociedade e, por isso, a história do capitalismo é

\footnotetext{
12 Tal compreensão da lei do valor supera a problemática da transformação dos valores em preços. Postone (2014) e Borges Neto $(2002,2004)$ tratam do assunto, que não será abordado aqui.

13 "O valor [...] é uma categoria de uma totalidade dinâmica. Essa dinâmica envolve uma dialética de transformação e reconstituição que resulta da natureza dual da forma-mercadoria e dos dois imperativos estruturais da forma de valor da riqueza - a busca de níveis crescentes de produtividade e a necessária retenção do trabalho humano direto na produção" (POSTONE, 2014, p. 356).
} 
marcada pela desigualdade, por conflitos distributivos e pela luta de classes.

O trabalho morto, o trabalho concreto acumulado das gerações passadas, aparece como algo alheio aos trabalhadores, o capital, que domina e estrutura as condições de trabalho e vida das pessoas (POSTONE, 2014). As pessoas são utilizadas pelo sistema econômico em vez de utilizarem os avanços científicos e tecnológicos acumulados para a melhoria das condições de trabalho e de vida. Em virtude da perene elevação da produtividade do trabalho social, o mesmo volume de produção de valores de uso pode ser feito por um número decrescente de trabalhadores. $\mathrm{O}$ volume de emprego em uma sociedade capitalista só aumenta se a produção crescer mais que a produtividade, como Marx deixa claro ao investigar a "lei geral da acumulação capitalista". Isso significa que, em uma sociedade na qual há um imperativo sistêmico ilimitado para a ampliação da produtividade, a produção tem que crescer ilimitadamente, para a manutenção do nível de emprego, gerando enormes pressões no meio ambiente. O desemprego e a destruição do meio ambiente também são tendências multisseculares do modo de produção capitalista $^{14}$ :

E todo progresso da agricultura capitalista é um progresso na arte de saquear não só o trabalhador, mas também o solo, pois cada progresso alcançado no aumento da fertilidade do solo por certo período é ao mesmo tempo um progresso no esgotamento das fontes duradouras dessa fertilidade. Quanto mais um país, como os Estados Unidos da América do Norte, tem na grande indústria o ponto de partida de seu desenvolvimento, tanto mais rápido se mostra esse processo de destruição. Por isso, a produção capitalista só desenvolve a técnica e a combinação do processo de produção social na medida em que solapa os mananciais de toda a riqueza: a terra e o trabalhador (MARX, 1867, p. 573-574).

Marx observara que o capitalismo apresenta tendências de se expandir pelo globo terrestre e de gerar inovações. Entretanto, não observou que as inovações tendem a se concentrar em áreas que já introduziram inovações anteriormente. Tais regiões, que tendem a conformar o centro (ou núcleo) do capitalismo global possuem elevados custos de infraestrutura, de serviços e de força de trabalho, mas conseguem originar produtos que se beneficiam de tais custos e os incorporam nos preços mais elevados que aqueles dos produtos originados em regiões mais periféricas. As regiões centrais conseguem repelir atividades menos dinâmicas para as áreas periféricas ou semiperiféricas do capitalismo $^{15}$. Ocorrem processos de "causação circular e acumulativa" à la Myrdal, nos

\footnotetext{
14 "Para Marx, esse padrão de crescimento [capitalista] tem duplo caráter: envolve a constante expansão da capacidade produtiva humana, ainda que vinculada a uma estrutura social dinâmica e alienada, essa expansão tem uma natureza acelerada, ilimitada e fugidia sobre a qual não se tem controle. Deixando de lado considerações de possíveis limites ou barreiras à acumulação de capital, uma das consequências implícitas por esta dinâmica particular - que gera mais crescimento na riqueza material do que no maisvalor - é a aceleração da degradação ambiental" (POSTONE, 2014, p. 360).

15 “[...] no ambiente típico da zona do núcleo orgânico - caracterizado por mercados remuneradores, infraestruturas e serviços eficientes e um clima político favorável à empresa capitalista - os custos altos não são um obstáculo, mas sim um incentivo ao fluxo contínuo de inovações que é necessário para reproduzir o status de zona do núcleo orgânico. Em contraste, no ambiente típico da zona periférica caracterizado por mercados fragmentados e descontínuos, infraestrutura e serviços ineficientes e um clima político frequentemente desfavorável à capacidade empresarial capitalista - os custos altos são incapazes
} 
quais as regiões com melhores infraestrutura e de qualificação da força de trabalho conseguem gerar renda para pagar por essas condições superiores e reproduzir e criar as atividades econômicas mais intensivas em tecnologia e em conhecimento ao longo do tempo. Assim como as atividades que demandam altos custos de produção no interior de uma economia nacional em particular são realizáveis por parcelas mais ou menos restritas da população, as atividades originadas no núcleo do capitalismo global podem ser reproduzidas em apenas umas poucas áreas e podem ser adquiridas no comércio internacional com preços relativos altos em comparação com a produção originada nas áreas com piores infraestrutura e qualificação (ARRIGHI, 1997).

Nos diversos territórios ocorrerão discrepâncias entre: os graus de domínio tecnológico; os níveis de produtividade e de intensidade do trabalho; a maneira como o aumento da produtividade se difunde; o desenvolvimento dos sistemas monetários, financeiros e bancários. Tais discrepâncias implicam na hierarquização espacial do capitalismo global, criando centros e periferias, no âmbito planetário.

A projeção das relações sociais capitalistas ao âmbito mundial também redunda na projeção da competição intercapitalista e dos conflitos entre frações de classe a todo o globo terrestre. Essa é a razão pela qual o imperialismo é uma tendência sempre presente. E por isso, a ênfase que os autores da escola francesa da regulação e da abordagem das estruturas sociais de acumulação dão ao nível nacional de análise dificulta a compreensão das diferentes formas do capitalismo, que se articulam, em vez de serem independentes.

Depois de observadas algumas das características mais essenciais do modo de produção, é necessário abordar as propriedades do sistema econômico que fazem com que a investigação histórica e a periodização do capitalismo sejam possíveis, ou mesmo necessárias, em níveis menos abstratos de compreensão. Essas características realizam a mediação entre a análise mais geral e abstrata e a análise histórica e institucional do capitalismo.

É essencial destacar que, mesmo no âmbito mais abstrato, a lógica mercantil não está presente em uma forma pura, alheia aos aspectos políticos e morais da sociedade. No caso da exposição de Marx em "O capital”, a jornada de trabalho e o valor da força de trabalho, por exemplo, são delimitados não apenas por fatores fisiológicos, mas também por fatores políticos e culturais. Também é muito importante notar que, mesmo no nível mais fundamental de investigação, o Estado está implícito. Ele é pressuposto para garantir a existência da propriedade privada, estabelecer regras na relação entre capitalistas e trabalhadores, garantir o funcionamento adequado da moeda e do sistema de crédito, administrar conflitos de interesses entre proprietários privados independentes, estabelecer regras quanto à interação da nação com outros países e prover uma infraestrutura física necessária para a produção e o comércio. Tal fato é consensualmente aceito por Smith, Marx, por outros autores relacionados com a economia política clássica e pelos autores ligados ao institucionalismo original, embora

de sustentar as inovações, enquanto que os custos baixos simplesmente oferecem um incentivo para organizar atividades periféricas" (ARRIGHI, 1997, p. 156). 
seja negligenciado por algumas versões da teoria neoclássica, como, por exemplo, as teorias do equilíbrio geral. Na origem do modo de produção capitalista, a existência do Estado-nação foi um pressuposto básico para a dissolução dos laços econômicos e de proteção feudais e, posteriormente, para a generalização das relações sociais capitalistas (WOOD, 1998).

Mesmo no plano mais básico de análise, é necessário ter em conta que o sistema econômico possui "impurezas", ou seja, é necessariamente ligado a sistemas que não se reduzem à lógica mercantil, entre os quais a família, o Estado e as relações internacionais. Esse argumento está presente, por exemplo, em um texto de Hodgson (2001) e outro de Hodgson, Itoh e Yokokawa (2001), nos quais os autores criticam a concepção defendida por Kozo Uno, de que seria necessário elaborar uma teoria estratificada do capitalismo tendo como nível mais abstrato de análise uma teoria pura do capitalismo, que, segundo Uno ${ }^{16}$ (1980), foi elaborada por Marx. O presente artigo advoga que a abordagem de Marx em "O capital” não pressupõe uma teoria pura do capitalismo. É importante ter em mente que existem importantes mercadorias fictícias, como o trabalho, a moeda e a natureza, que não são reprodutíveis pela lógica dos mercados (POLANYI, 1944). Mesmo o funcionamento normal dos mercados pressupõe a inserção desses em um ambiente cultural e social irredutível ao mercado.

Assim, o capitalismo nem é um absoluto hegeliano isento de fissuras nem se reduz às suas manifestações históricas, como o capitalismo liberal inglês do século XIX, o imperialismo, ou o capitalismo do pós-guerra ${ }^{17}$. Seguindo a leitura de Hegel e de Marx realizada pelo filósofo esloveno Slavoj Žižek (2008, p. 54), o próprio “universal” é cindido, ontologicamente marcado pelo antagonismo: "O Universal não é o receptáculo abrangente do conteúdo particular, o background pacífico do conflito de particularidades; o Universal 'como tal' é o local de um antagonismo insuportável, de

${ }^{16}$ A principal característica da escola unoísta de economia política é a distinção entre três níveis de análise do capitalismo: a teoria pura, a teoria das etapas do capitalismo e a análise histórica (SEKINE, 1975; CLARKE, 1989; BELL, 2009). De acordo com Uno (1980), a teoria pura trata de elementos gerais, abstratos, do modo de produção, ao analisar um ambiente hipotético governado pela lei do valor e sua lógica. A introdução de outras lógicas (derivadas principalmente da luta de classes, da ação do Estado e dos diferentes valores de uso produzidos) no sistema teórico permitiria que fossem estudadas as etapas do capitalismo. Por fim, uma análise mais detalhada do comportamento real do sistema econômico só seria possível de um ponto de vista histórico. A abordagem de Uno, que não será analisada com profundidade no presente artigo, é criticada por considerar a possibilidade da existência de uma economia pura e por adotar um ponto de vista teleológico acerca da superação do capitalismo, que estaria em transição para uma sociedade socialista já a partir de 1914 (CLARKE, 1989; HODGSON 2001).

17 Žižek (2008, p. 53) critica o "historização nominalista", por exemplo, no contexto da defesa de "modernidades alternativas": "A importância dessa crítica [às modernidades alternativas] vai bem além do caso da modernidade: ela diz respeito à limitação fundamental da historização nominalista. O recurso à multiplicação ('não já uma modernidade única, com uma essência fixxa, há modernidades múltiplas, cada uma irredutível às outras...') é falso não porque não reconheça a 'essência' fixa e única da modernidade, mas porque a multiplicação funciona como repúdio do antagonismo inerente à noção de modernidade como tal: a falsidade da multiplicação reside no fato de libertar a noção universal de modernidade de seu antagonismo, da maneira como está embutida no sistema capitalista, por relegar esse aspecto a apenas uma de suas subespécies históricas". 
autocontradição, e (a miríade de) suas espécies particulares, em última análise, nada mais são que tentativas múltiplas de confundir/conciliar/dominar esse antagonismo".

Desse modo, uma teoria abstrata do modo de produção capitalista não pode ser uma concepção totalmente fechada em si mesma, deve comportar aberturas, pois importantes variáveis do sistema econômico são determinadas por dinâmicas não econômicas (por exemplo, o tipo de relação capital-trabalho predominante, o tipo de padrão monetário etc.). Desde o início do século XX, o caráter aberto de muitos dos principais elementos da economia capitalista é captado pelo conceito de instituição. Desse ponto de vista, as mudanças de etapas do capitalismo podem ser compreendidas como transformações dos conjuntos de instituições.

\section{Quadro 1: Tendências e Propriedades Multisseculares do Capitalismo}

\begin{tabular}{|l|l|}
\hline \hline Fundamentos & Tendências Imultisseculares \\
\hline Mercado & $\begin{array}{l}\text { Criação da moeda } \\
\text { Crise } \\
\text { Crédito/capital fictício }\end{array}$ \\
\hline Capital-trabalho & $\begin{array}{l}\text { Inovação e produtividade } \\
\text { Mundo do trabalho é central } \\
\text { Exclusão/conflitos distributivos e de gênero } \\
\text { Desemprego } \\
\text { Destruição ambiental }\end{array}$ \\
\hline \multirow{2}{\text{Espacialidade}}{} & $\begin{array}{l}\text { Criação de centros/periferias } \\
\text { Internacionalização } \\
\text { Imperialismo }\end{array}$ \\
\hline $\begin{array}{l}\text { Esfera não } \\
\text { mercantil }\end{array}$ & $\begin{array}{l}\text { Importância das instituições } \\
\text { Variedades do capitalismo }\end{array}$ \\
\hline \hline
\end{tabular}

Fonte: Elaboração própria.

Uma vez admitida a importância das impurezas no sistema econômico, torna-se lógica a possibilidade de existência de variedades do capitalismo. Além disso, torna-se importante a análise de outras temporalidades históricas para a compreensão da economia. O Quadro 1, acima, sintetiza as considerações principais acerca da tendências e propriedades multisseculares do capitalismo, derivadas das relações sociais fundamentais.

É importante destacar que, de forma alguma, a consideração da importância de se compreender as mudanças históricas e qualitativas do capitalismo impede que sejam investigados os elementos estruturais e imutáveis do modo de produção. A ausência de uma investigação das estruturas multisseculares do sistema econômico pode levar a considerações equivocadas sobre o capitalismo. As próprias fissuras e os antagonismos presentes no modo de produção capitalista impedem que a sua análise seja totalmente reduzida tanto às suas características básicas quanto às suas manifestações históricas. Com o intuito de conciliar a investigação das propriedades básicas do capitalismo com a necessária variabilidade das economias reais, a economia política e, mais 
especificamente, Marx, investigaram o sistema econômico com base em leis tendenciais, que poderiam ou não se manifestar, dependendo do comportamento de uma série de variáveis, que não podiam ser reduzidas à lógica econômica.

\section{Introdução à Periodização do Capitalismo Neoliberal}

Com inspiração crítica nas elaborações de Marx, Hobson, Lênin, Hilferding, Keynes, Schumpeter, Gramsci, Polanyi e outros autores, a escola da regulação, a escola das estruturas sociais de acumulação e a escola neoschumpeteriana avançaram em relação às teorias do imperialismo e do capitalismo monopolista, ao identificarem a relação salarial, o padrão monetário, a forma de inserção internacional, o tipo de Estado, o padrão tecno-organizacional, as correlações de frações de classe como as formas institucionais principais para a compreensão das etapas do capitalismo. Entretanto, por deixar em segundo plano a investigação sobre as características básicas do modo de produção capitalista, as teorias sobre as etapas do capitalismo acabaram tendo dificuldade de compreender as transformações históricas do modo de produção.

Devido ao caráter expansivo e internacionalizante das relações sociais capitalistas, não é possível a compreensão do modo de produção capitalista ou das diferentes etapas do mesmo do ponto de vista das economias nacionais. Por essa razão, serão apresentadas, na presente seção, características da economia global das últimas décadas. Tais características não se reduzem à soma das partes do sistema econômico (MCNALLY, 2009) $^{18}$.

O Quadro 2 abaixo apresenta as instituições como diferentes formas nas quais aparecem as relações sociais fundamentais do modo de produção. Enquanto as relações fundamentais são responsáveis pelas tendências e propriedades multisseculares do capitalismo, as diferentes configurações institucionais podem dar origem a diversas tendências específicas, que serão discutidas a seguir. A análise mais adequada das etapas do capitalismo deve levar em conta tanto tendências multisseculares quanto as propriedades de época.

Por exemplo, no caso do imperialismo, predominava o padrão monetário lastreado em ouro, a classe trabalhadora estava se organizando, mas não tinha muito poder político. Este estava mais concentrado nas mãos dos capitalistas industriais e financeiros. O Estado desempenhava um papel restrito na economia, destacando-se notadamente nas atividades militares. Não havia política econômica anticíclica e havia pouca regulamentação do setor financeiro, o que fazia com que as crises tendessem a ser agudas e deflacionárias. O crescimento econômico era, pelo menos em parte, liderado pela exploração colonial e pelo militarismo. A coesão social era frágil e baseada

18 Amin (1994) e Medeiros (1998) criticam a ênfase nacional das teorias sobre a "era de ouro". Recentemente, a escola das estruturas sociais de acumulação e a abordagem da regulação estão começando a deixar em segundo plano a ênfase no ponto de vista das economias nacionais - que predominava até o início do século XXI (KOTZ, MCDONOUGH, REICH, 1994a; BOYER, SAILLARD, 2002; BOYER, 2004) - e estão começando a desenvolver análises internacionais das mudanças do capitalismo (MCDONOUGH, REICH, KOTZ, 2010; BOYER, 2015). 
nas rivalidades internacionais, raciais e de classe. A proteção social era restrita. As tendências de longa duração de ocorrência de crises econômicas, de geração de desemprego e de eclosão de conflitos sociais fizeram com que o imperialismo, com o tempo, deixasse de ser o tipo de capitalismo típico dos países centrais.

\section{Quadro 2: Relações Sociais Fundamentais, Instituições e Tendências Específicas}

\begin{tabular}{|l|l|l|}
\hline Fundamentos & Instituições & Tendências específicas \\
\hline Mercado & Padrão monetário & $\begin{array}{l}\text { Crises inflacionárias e deflacionárias } \\
\text { Crédito gera crescimento/crise }\end{array}$ \\
\hline Capital-trabalho & $\begin{array}{l}\text { Relação salarial } \\
\text { Correlações de classe } \\
\text { Padrão técnico- } \\
\text { organizacional }\end{array}$ & $\begin{array}{l}\text { Conflito/compromisso } \\
\text { Consumo em massa/consumo restrito } \\
\text { Coesão social com emprego/ } \\
\text { militarismo/consumismo }\end{array}$ \\
\hline Concorrência & $\begin{array}{l}\text { Inserção } \\
\text { internacional }\end{array}$ & $\begin{array}{l}\text { Fluxos de capital/comércio } \\
\text { Militarismo/diplomacia }\end{array}$ \\
\cline { 1 - 3 } Espacialidade & $\begin{array}{l}\text { Forma do Estado } \\
\text { Laços de proteção }\end{array}$ & $\begin{array}{l}\text { Estado interventor/liberal } \\
\text { Tipo de proteção social }\end{array}$ \\
\hline
\end{tabular}

Fonte: Elaboração própria.

No pós-guerra foi formada uma nova etapa que, assim como a etapa imperialista, também era idiossincrática e não a última forma histórica possível de capitalismo. Nos países centrais, ocorreu a chamada "era de ouro", baseada em aumentos salariais, no Estado intervencionista, na ampliação da proteção social e no crescimento tanto do consumo quanto da produção em massa. A coesão social era garantida pelo consenso em torno da melhoria do padrão de vida, facilitada pela reconstrução dos países europeus e pela ajuda americana, no contexto da Guerra Fria e de movimentos operários fortes. Entretanto, as tendências multisseculares, como a internacionalização do capital, a formação de centros e periferias, os conflitos distributivos e de classes sociais contribuíram com a erosão das formas institucionais. No restante deste tópico, serão apresentadas características e tendências associadas às duas últimas etapas do capitalismo, o padrão de crescimento do pós-guerra, que predominou, aproximadamente, entre 1950-1973 e o capitalismo neoliberal, que predomina entre a década de 1980 e os dias atuais ${ }^{19}$.

$\mathrm{Na}$ "era de ouro", o crescimento econômico se dava de modo muito mais acelerado que da década de 1980 em diante. Os dados da Tabela 1 mostram que, para os países selecionados, apenas o Reino Unido teve crescimento médio inferior a $4 \%$ ao ano entre 1961 e 1970. Nessa década, o Japão apresentou taxa média de crescimento superior a $9 \%$ ao ano. Na década de 1970, o Brasil cresceu, em média, 8,5\% ao ano,

\footnotetext{
${ }^{19} \mathrm{O}$ neoliberalismo é entendido, no presente artigo, como um projeto político e um tipo de capitalismo que favorece a maior liberdade de acumulação de capital e a ampliação do poder político e econômico da classe capitalista, em comparação ao padrão de crescimento do pós-guerra. Apesar da retórica neoliberal defender a diminuição do tamanho do Estado, ou mesmo o Estado mínimo, tais proposições são muito mais retóricas do que aplicadas na prática (HARVEY, 2008, p. 27; KOTZ, MCDONOUGH, REICH, 2010).
} 
graças ao abundante acesso ao crédito externo, alimentado pela reciclagem dos eurodólares e, posteriormente, dos petrodólares ${ }^{20}$.

Tabela 1: Taxa Média de crescimento do PIB, Países Selecionados, 1961-2016

\begin{tabular}{l|c|c|c|c|c|c}
\hline \hline País Década & $1961-70$ & $1971-80$ & $1981-90$ & $1991-2000$ & $2001-10$ & $2011-16$ \\
\hline Alemanha & - & 2,9 & 2,3 & 2,0 & 0,9 & 1,7 \\
\hline Argentina & 4,0 & 3,0 & $-1,4$ & 4,7 & 3,7 & 0,9 \\
\hline Brasil & 6,2 & 8,5 & 1,8 & 2,6 & 3,7 & 0,3 \\
\hline China & 5,0 & 6,3 & 9,3 & 10,5 & 10,6 & 7,7 \\
\hline EUA & 4,5 & 3,2 & 3,4 & 3,4 & 1,7 & 2,1 \\
\hline Japão & 9,3 & 4,5 & 4,6 & 1,3 & 0,7 & 1,5 \\
\hline Reino Unido & 3,3 & 2,2 & 2,9 & 2,5 & 1,6 & 2,0 \\
\hline \hline
\end{tabular}

Fonte: Banco Mundial. Elaboração própria.

Entre as décadas de 1950 e 1970, ocorreu, em vários países avançados, o que a escola francesa da regulação chama de "compromisso fordista" e a escola das estruturas sociais de acumulação chama de "acordo capital-trabalho". Tal acordo possibilitou que o salário real crescesse em ritmo próximo do crescimento da produtividade. Esse foi um dos principais fatores para o crescimento sustentado da demanda agregada. Outro fator foi a ampliação do gasto público bem acima no crescimento médio da economia.

Em alguns países, com destaque para os Estados Unidos, o gasto militar foi um dos motores do crescimento. Ademais, a construção de redes de proteção social garantiu que as transferências sociais de Alemanha, Japão, Reino Unido e Estados Unidos, por exemplo, passassem de respectivamente, $4,8 \%, 0,2 \%, 2,2 \%$ e $0,6 \%$ do PIB desses países em 1930 para 25,7\%, 11,9\%, 16,4\% e $15 \%$ do PIB em 1980, conforme a Tabela 2 a seguir. Dessa última década em diante, as transferências sociais cresceram significativamente apenas no Reino Unido.

Conforme a Tabela 1, depois do ano 2000, apenas um país da amostra conseguiu uma média de crescimento superior a 4\%, a China, que pratica uma agressiva política desenvolvimentista e de conquista de mercado externo. A China obteve crescimento médio superior a $9 \%$ ao ano entre 1981 e 2010. A entrada do país no âmbito do mercado mundial fez com que centenas de milhões de trabalhadores, em pouco tempo, fossem inseridos no mercado de trabalho, gerando uma pressão competitiva muito elevada nesse mercado, a qual restringe o crescimento dos salários no âmbito mundial. $\mathrm{O}$ Gráfico 1 apresenta dados da Organização Internacional do Trabalho, que indicam a existência de uma defasagem entre o crescimento da produtividade e o crescimento do

${ }^{20}$ Não é possível desenvolver, de modo exaustivo, as características do capitalismo das últimas décadas. Vários autores aprofundaram esse tema. Alguns capítulos de Kotz, McDonough e Reich (2010) apresentam a visão da escola das estruturas sociais de acumulação sobre as transformações do capitalismo no século XX. Boyer (2015), líder da escola da regulação, apresenta sua visão. Alguns autores marxistas também desenvolvem o tema, com ênfase no capitalismo financeiro (CHESNAIS, 2016), na reestruturação do sistema produtivo (MCNALLY, 2009) e nas políticas econômicas adotadas pelos países centrais (BRENNER, 2009). 
salário real médio para o conjunto de 36 economias avançadas. Para alguns dos países avançados, como os EUA, essa defasagem existe pelo menos desde o início da década de 1970.

Tabela 2: Transferências Sociais como parcela do PIB, Países Selecionados, 19301995

\begin{tabular}{|c|c|c|c|c|c|}
\hline $\begin{array}{lll}\text { País } & \text { Ano } \\
\end{array}$ & 1930 & 1960 & 1970 & 1980 & 1995 \\
\hline Alemanha & 4,8 & 18,1 & 19,5 & 25,7 & 24,9 \\
\hline Japão & 0,2 & 4,1 & 5,7 & 11,9 & 12,2 \\
\hline Reino Unido & 2,2 & 10,2 & 13,2 & 16,4 & 22,5 \\
\hline EUA & 0,6 & 7,3 & 10,4 & 15,0 & 13,7 \\
\hline
\end{tabular}

Fonte: Lindert (2004). Elaboração própria.

Além do aumento da competição internacional, a perda de poder dos sindicatos contribui para a diminuição dos ganhos salariais reais. De acordo com Schnabel (2013, p. 257), entre 1980 e 2010, o total da força de trabalho sindicalizada reduziu de $39 \%$ para $24 \%$ na Alemanha, de $31,1 \%$ para $18,5 \%$, no Japão, de cerca de $50 \%$ para $27,5 \%$ no Reino Unido e de 22,3\% para $11,4 \%$, nos EUA ${ }^{21}$.

\section{Gráfico 1: Produtividade e Salário Real Médio para 36 Países Desenvolvidos}

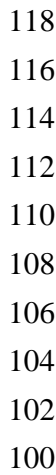

ஓ

Fonte: OIT Global Wage Report 2014/15 e BLS. Elaboração própria. Ano base 1999.

Devido ao aumento restrito dos salários reais, a ampliação do consumo das famílias tem sido garantida pelo endividamento. O Gráfico 2, abaixo, apresenta a dívida

\footnotetext{
${ }^{21}$ As principais causas da "compressão de salários", segundo McNally $(2009$, p. 60) são: i) a relocalização da produção; ii) a enorme expansão da força de trabalho global; iii) o aumento da produtividade resultante da produção enxuta e de mudanças tecnológicas; iv) o aumento da jornada de trabalho; v) enfraquecimento dos sindicatos e redução dos direitos sociais.
} 
total das famílias como parcela da renda líquida disponível, para alguns países selecionados. Em meados dos anos 1990 a dívida das famílias já era superior à renda líquida disponível em alguns países avançados, como os Estados Unidos, o Reino Unido, o Japão e a Alemanha. A partir do ano 2000, ocorreu grande aumento do endividamento das famílias nos Estados Unidos e no Reino Unido, especialmente em virtude da bolha do endividamento imobiliário, mas também em virtude das dívidas com cartão de crédito e do crédito estudantil. Um dado que merece destaque é o endividamento relativamente baixo das famílias brasileiras, mas que não deve ser desconsiderado, em virtude das altas taxas de juros prevalecentes no país.

O desempenho econômico bastante dependente do endividamento e das bolhas de ativos é uma das principais causas da instabilidade econômica e do baixo crescimento identificados na Tabela 1. Em virtude do consumo das famílias crescer em grande medida com base no endividamento e em virtude dos salários crescerem relativamente pouco, no âmbito mundial, como decorrência da forte concorrência da produção do Leste Asiático, especialmente chinesa, as taxas de lucro, que atingiram níveis mínimos entre meados da década de 1970 e o início da década de 1980, voltaram a crescer, como atesta o Gráfico 3, que apresenta o retorno líquido para o estoque líquido de capital da economia para os Estados Unidos, o Reino Unido e a Alemanha.

\section{Gráfico 2: Dívida Total das Famílias Como Parcela da Renda Líquida Disponível, 1995-2015}

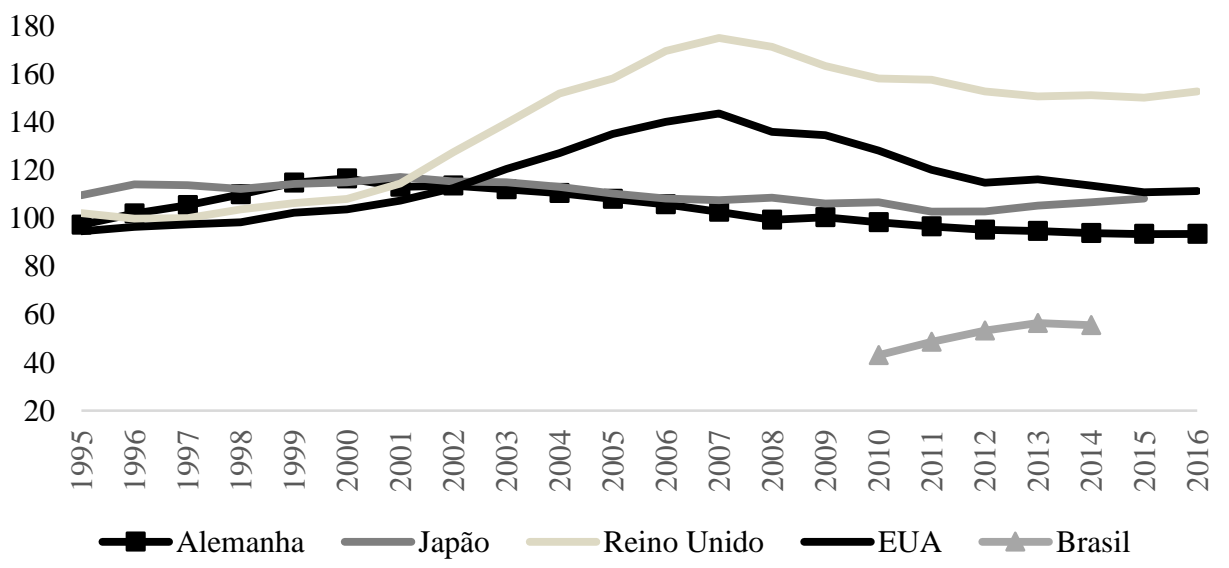

Fonte: OCDE. Elaboração própria.

A escola francesa da regulação, a abordagem das estruturas sociais de acumulação e a escola neoschumpeteriana, como visto anteriormente, tiveram dificuldade em compreender o padrão de crescimento da década de 1980 em diante como um padrão viável, embora instável e responsável por menores taxas de crescimento. Alguns autores marxistas destacam a queda da taxa de lucro como um fator central para explicar a dinâmica do capitalismo contemporâneo (DUMÉNIL, LEVY, 
2004; CHESNAIS, 2016).

Os dados do Gráfico 3 e outras estimativas para a taxa de lucro (HUSSON, 2010; MCNALLY, 2009) indicam que a lucratividade aumentou, em relação à década de 1980, portanto estaria descartada a queda da taxa de lucro como um dos fundamentos principais para o baixo crescimento e as crises do período neoliberal. A análise das transformações do capitalismo nas últimas décadas não deve ser centrada em apenas um elemento (como a taxa de lucro ou a financeirização, por exemplo), mas deve levar em conta mudanças, em âmbito mundial, ocorridas no modo de produção capitalista (BRENNER, 2009; MCNALLY, 2009).

O baixo crescimento econômico das últimas décadas vem sendo liderado pelo aumento do endividamento, pelos déficits fiscais nos âmbitos nacionais e pelos elevados déficits comerciais estadunidenses, no plano internacional. Os consumidores nos Estados Unidos se beneficiam da posição privilegiada do dólar para se tornarem "consumidores em última instância", no âmbito mundial.

\section{Gráfico 3: Taxa de Lucro (retorno líquido para o estoque líquido de capital da economia)}

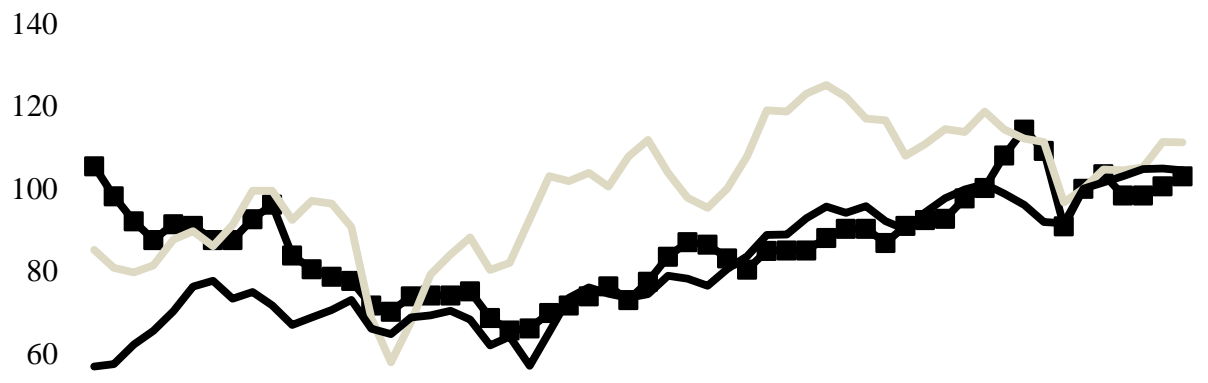

40

20

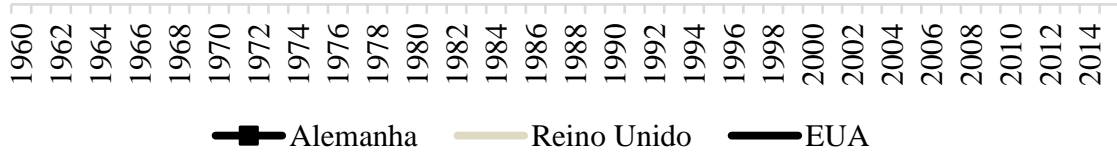

Fonte: Annual macro-economic database of the European Commission (Ameco). Ano base 2010. Elaboração própria. 


\section{Gráfico 4: Índice de Shiller de Preço/Lucro por Ação do S\&P 500, 1881-2018}

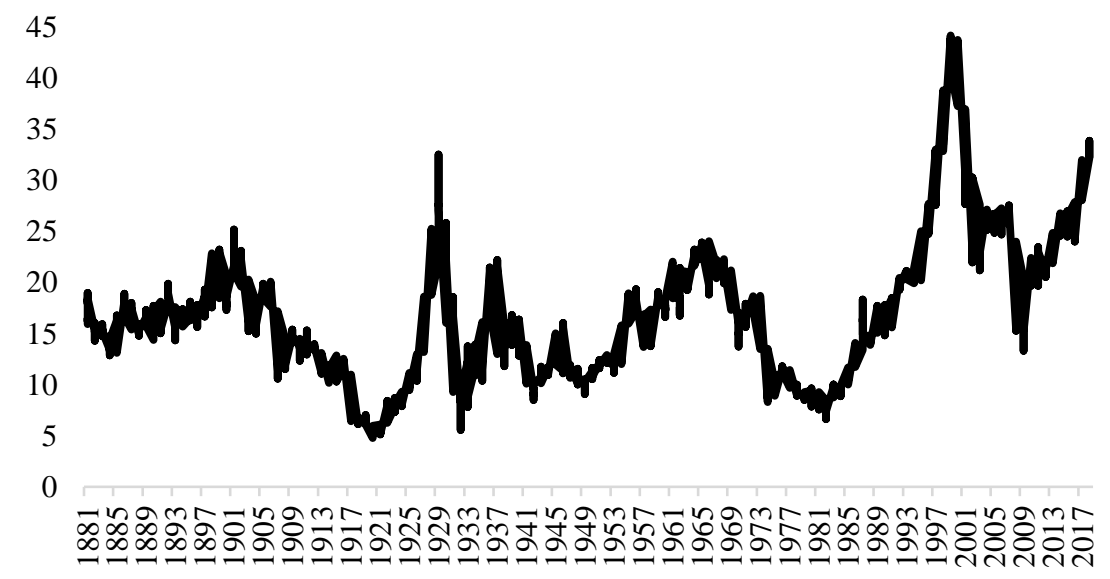

Fonte: https://www.quandl.com. Razão entre preço das ações e lucro médio nos últimos 10 anos. Elaboração própria.

Os déficits fiscais e comerciais dos Estados Unidos, por sua vez, vêm alimentando os mercados financeiros (tanto do país quanto internacionais), que crescem em ritmo muito superior ao das economias reais. O Gráfico 4 apresenta o índice de Shiller, entre o preço das ações e a lucratividade das empresas do S\&P 500 entre 1881 e março de 2018. Pode-se observar que, enquanto a média histórica desse índice é de pouco mais de 16 pontos, a média posterior ao ano 2000 é de cerca de 25 pontos e o índice atingiu mais de 40 pontos no auge da bolha das empresas "ponto com" entre 1999 e 2000 (o máximo anterior havia sido de 32,5 pontos em setembro de 1929). Uma elevada razão entre o preço total das ações da S\&P 500 e o lucro real médio das empresas indica um descolamento entre o mercado acionário e a economia real.

O elevado crescimento da taxa de lucro e do mercado financeiro associados ao baixo crescimento dos salários provoca uma acentuada concentração de renda, nas últimas décadas, ilustrada no Gráfico 5, a seguir. Países como Estados Unidos, Alemanha e Brasil apresentam concentração de renda próxima ou mesmo superior à encontrada no período da Crise de 1929. A desconcentração de renda entre a década de 1940 e o final da década de 1970, em países como Estados Unidos, Alemanha e Reino Unido é um indício do acordo capital-trabalho, ou do pacto fordista, típico da "era de ouro" do capitalismo. O Gráfico 5 permite observar que esse tipo de pacto não aconteceu no Brasil.

Desde os anos 1980 tem prevalecido um tipo de capitalismo que, muitas vezes, é caracterizado como neoliberal. Nesse tipo de capitalismo, vem ocorrendo a ampliação (em comparação com a "era de ouro") dos fluxos internacionais de capital e de comércio. Devido à concorrência internacional, os trabalhadores têm menor poder político. Os Estados estão se preocupando menos com a estabilidade econômica e com 
políticas de bem-estar social e mais com o combate à inflação e a austeridade fiscal. $\mathrm{O}$ crescimento econômico é relativamente baixo e, em parte, alimentado por inevitáveis déficits fiscais e pelo endividamento das famílias. A coesão social não é garantida pela forma compromisso, predominante no pós-guerra, mas pelo consumismo, pelo nacionalismo, pelo militarismo e pela xenofobia. As crises financeiras recorrentes nas últimas décadas ainda não foram suficientes para uma nova transformação do capitalismo, mas a instabilidade política e econômica crescente, pelo menos desde 2008, indica que novas formas institucionais podem ser construídas. Apesar da instabilidade favorecer a reforma social, não necessariamente ocorrerão mudanças institucionais e estas não necessariamente serão progressistas. Não está descartado o aumento do totalitarismo no âmbito mundial.

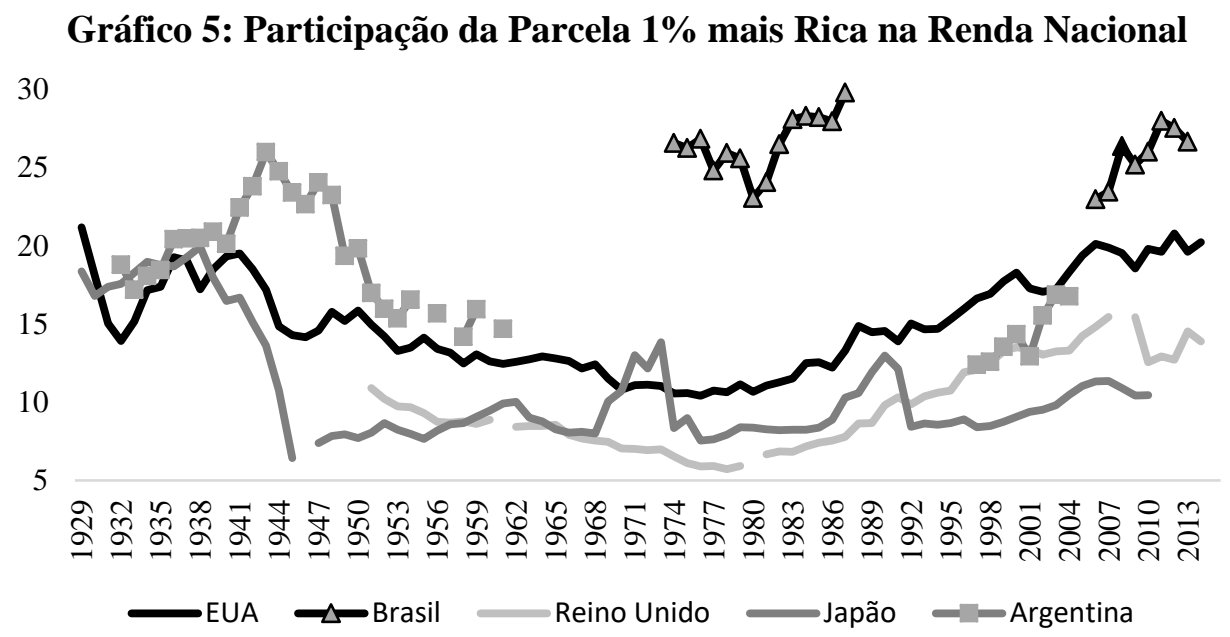

Fonte: World Income Database; Milá (2015). Elaboração própria.

Muitas das teorias sobre as etapas do capitalismo - notadamente a abordagem das estruturas sociais de acumulação, a escola francesa da regulação e a abordagem neoschumpeteriana - adotam pontos de vista da economia crítica e propõem mudanças institucionais para que sejam criados modelos de crescimento relativamente mais favoráveis aos trabalhadores. Embora não seja necessário descartar a defesa desse tipo de mudança institucional, do ponto de vista da crítica da economia política é necessário pensar em mudanças políticas que superem as contradições fundamentais do modo de produção capitalista, como o aumento da desigualdade, a substituição do trabalho vivo pelo trabalho morto e a destruição do meio ambiente ao nível planetário, fenômenos resultantes do processo de violenta abstração ${ }^{22}$ realizada pela lógica do capital, que

22 O processo de "abstração violenta" (ou "abstração forçada") não é um fenômeno que ocorre apenas na mente dos indivíduos (MARX, 1867, p. 378-379; MCNALLY, 2009, p. 69-72), mas é um processo que decorre do próprio movimento de autovalorização do capital. 
reduz as pessoas e a natureza a momentos do seu movimento de expansão desmedida ${ }^{23}$.

\section{Considerações Finais}

O presente artigo argumenta que é possível articular a análise das tendências multisseculares do modo de produção com a análise das características específicas a cada espaço geográfico e a cada período histórico. Desse modo, poderia ser retomado o projeto original de diversas teorias das etapas do capitalismo: a conjugação de uma teoria geral do capitalismo com a periodização do sistema econômico. Este texto não advoga que as teorias sobre as etapas do capitalismo devam ser abandonadas. Pelo contrário, o entendimento do capitalismo atual, muitas vezes caracterizado como financeirizado, ou como neoliberal, passa necessariamente pela periodização do capitalismo. Além disso, o reconhecimento da existência tanto das características gerais do modo de produção quanto das características específicas do capitalismo pode permitir um diálogo mais aprofundado entre diferentes escolas de pensamento econômico, tais como o marxismo, o institucionalismo e o keynesianismo, abordagens ocupadas com níveis diferentes da realidade, que se associam a diferentes escalas de tempo.

Por fim, o entendimento das características mais gerais do modo de produção não exclui a compreensão da historicidade deste, mas, pelo contrário, possibilita que se vislumbre a articulação necessária entre a economia, a política, as relações internacionais e outras áreas do conhecimento humano, permitindo uma melhor compreensão das mudanças qualitativas do capitalismo e do funcionamento concreto da vida econômica.

\section{Referências}

AGLIETTA, M. A theory of capitalist regulation: the US experience. Londres e Nova York, Verso, 2000 (1976).

AMIN, S. A propos de la régulation. In: SEBAÏ, F; VERCELLONE, C. (Eds.). Ecole de la régulation et critique de la raison économique. Paris, L'Harmattan (número especial da Futur Antérieur), 1994.

ARRIGHI, G. A ilusão do desenvolvimento. Petrópolis, Editora Vozes, 1997.

BARAN, P; SWEEZY, P. Monopoly capital. Nova York, Monthly Review Press, 1966.

BELL, J. Capitalism and the dialetic: the Uno-Sekine approach to marxian political economy. Nova York, Pluto Press, 2009.

${ }^{23} \mathrm{O}$ presente artigo não se propõe a apresentar propostas para a superação das contradições fundamentais do capitalismo. Essa difícil missão deve continuar a ser enfrentada pela crítica da economia e, fundamentalmente, pelos movimentos sociais e políticos. 
BORGES NETO, J. Duplo caráter do trabalho, valor e economia capitalista. Tese (Doutorado em Economia) - Faculdade de Economia e Administração, USP, 2002.

BORGES NETO, J. As várias dimensões da lei do valor. Nova Economia, Vol. 14, No. 3, 2004.

BOWLES, S; GORDON, D; WEISSKOPF, T. Beyond the waste land: a democratic alternative to Economic Decline. Nova York, Doubleday, 1984.

BOWLES, S; GORDON, D; WEISSKOPF, T. After the waste land: a democratic economics for the year 2000. Armonk, M. E. Sharpe Inc., 1990.

BOYER, R. A teoria da regulação: uma análise crítica. São Paulo, Nobel, 1990.

BOYER, R. Os modos de regulação na época do capitalismo globalizado: depois do boom, a crise? In: FlORI, J. L; TAVARES, M. C; RAMONET, I; CASTEL, R; HIRST, P; BOYER, R. (Orgs.). Globalização: o fato e o mito. Rio de Janeiro, Ed. UERJ, 1998.

BOYER, R. Théorie de la régulation, Vol. 1: les fondamentaux. Paris, La découverte, collection Repères 2004.

BOYER, R. Les financiers détruiront-ils le capitalisme? Paris,Economica, 2011.

BOYER, R. Économie politique des capitalismes: théorie de la régulation et des crises. Paris, La découverte, 2015.

BOYER, R; SAILLARD, Y. (Eds.). Théorie de la régulation: 1'état des savoirs. Paris, La découverte, collection Recherches, nouvelle édition complétée, 2002.

BRAUDEL, F. Escritos sobre a História. São Paulo, Perspectiva, 1992.

BRENNER, R. Reply to critics. Comparative Studies of South Asia, Africa and the Middle East, Vol. XIX, No. 2, 1999.

BRENNER, R. What is good for Goldman Sachs is good for America: the origins of the present crisis.

www.sscnet.ucla.edu/issr/cstch/papers/BrennerCrisisTodayOctober2009.pdf. Acesso em 15/06/2017. Texto não publicado, 2009.

BUKHARIN, N. A economia mundial e o imperialismo. São Paulo, Nova Cultural (Coleção Os Economistas), 1986 (1917).

CHESNAIS, F. Finance capital today: corporations and banks in the lasting global slump. Boston, Lieden, 2016.

CLARKE, S. The basic theory of capitalism: a critical review of Itoh and the Uno school. Capital \& Class, No. 13, 1989.

DOI: https://doi.org/10.1177/030981688903700108 
CLARKE, S. Overaccumulation, class struggle and the regulation approach. In: BONEFELD, W; HOLlOWAY, J. Post-fordism \& social form: a Marxist debate on the post-fordist state. Londres, MacMillan Academic and Professional, 1991.

CORIAT, B. La théorie de la régulation: origines, spécificités et perspectives. In: SEBAÏ, F; VERCELLONE, C (Eds.). Ecole de la régulation et critique de la raison économique. Paris, L'Harmattan (número especial da Futur Antérieur), 1994.

COUTROT, T. The american radicals: a subversive current at the heart of the empire. In: BIDET, J; KOUVELAKIS, S. Critical companion to contemporary marxism. Chicago, Haymarket Books, 2009.

DUMÉNIL, G; LÉVY, D. Capital resurgent: roots of neoliberal revolution.

Cambridge, Harvard University Press, 2004.

FREEMAN, C. Social inequality, technology and economic growth. In: SENKER, P; WYARR, S. (Eds.) Technology and inequality. Londres, Routledge, 2000.

FREEMAN, C. Continental, national and sub-national innovation systems: complementarity and economic growth. Research policy, n. 31, 2002.

DOI: https://doi.org/10.1016/S0048-7333(01)00136-6

FREEMAN, C; LOUÇÃ, F. Ciclos e crises no capitalismo global: das revoluções industriais à revolução da informação. Porto, Edições Afrontamento, 2004.

FOSTER, J. B; MAGDOFF, F. The great financial crisis: causes and consequences. Nova York, Monthly Review Press, 2009.

GORDON, D. Up and down the long roller coaster. In: Union for Radical Political Economics (Eds.). US capitalism in crisis. Nova York, Union for Radical Political Economics, 1978.

GORDON, D; EDWARDS, R; REICH, M. Divided works, segmented workers: the historical transformation of labour in the United States. Nova York, Cambridge University Press, 1982.

GROSSMAN, H. The law of accumulation and breakdown of the capitalist system. Londres, Pluto Press, 1992 (1929).

HARVEY, D. The new imperialism. Oxford, Oxford University Press, 2003. HAUG, F. Marx within feminism. In: MOJAB, S (Ed.). Marxism and Feminism. Londres, Zed Books, 2015

HILFERDING, R. O capital financeiro. São Paulo, Nova Cultural (Coleção Os Economistas), 1985 (1910).

HOBSON, J. A. Imperialism: a study. Nova York, James Pott \& Co., 1902.

HODGSON, G. The evolution of capitalism from the perspective of institutional and evolutionary economics. In: HODGSON G; ITOH, M; YOKOKAWA, N. (Eds.). Capitalism in evolution: global contentions - East and West. Cheltenham, Edward Elgar, 2001. 
HODGSON G; ITOH, M; YOKOKAWA, N. Introduction. In: HODGSON G; ITOH, M; YOKOKAWA, N. (Eds.). Capitalism in evolution: global contentions - East and West. Cheltenham, Edward Elgar, 2001.

HUSSON, M. Le débat sur le taux de profit. Inprecor, No. 562-563, 2010.

KOTZ, D. The state, globalization and phases of capitalist development. In: ALBRITTRON, R; ITOH, M; WESTRA, R; ZUEGE, A. Phases of capitalist development: booms, crises, and globalizations. Nova York, Palgrave, 2001. KOTZ, D; MCDONOUGH, T. Global neoliberalism and the contemporary social structure of accumulation. In: MCDONOUGH, T; REICH, M; KOTZ, D.

Contemporary capitalism and its crises: social structure of accumulation theory for the $21^{\text {st }}$ Century. Nova York, Cambridge University Press, 2010.

KOTZ, D; MCDONOUGH, T; REICH, M. (Eds.). Social structures of accumulation: the political economy of growth and crisis. Nova York, Cambridge University Press, 1994a.

KOTZ, D; MCDONOUGH, T; REICH, M. Introduction. In: KOTZ, D; MCDONOUGH, T; REICH, M. (Eds.). Social structures of accumulation: the political economy of growth and crisis. Nova York, Cambridge University Press, 1994b.

LÊNIN, V. Imperialismo, etapa superior do capitalismo. Campinas, Navegando Publicações, 2011 (1917).

LINDERT. Growing public: social spending and economic growth since the eighteenth century. Cambridge, Cambridge University Press, 2004.

LIPIETZ, A. Miragens e Milagres. Problemas da Industrialização do Terceiro Mundo. São Paulo, Nobel, 1988.

LIPIETZ, A. Quelles régulations internationales pour le XXIe siècle? Revue Politique, abril, 2012.

LIPIETZ, A. La trop évitable crise européenne. In: AUFFREY-SÉGUETTE, M; FERRY, J.-M. LECLERC, A. Crise et critique. Paris, Presses Univ. de ParisSorbonne, 2015.

LIPPIT, V. The neoliberal era and the financial crisis in the light of SSA theory. Review of Radical Political Economics, Vol. 46, No. 2, 2013.

DOI: https://doi.org/10.1177/0486613413497908.

LOUÇÃ, F. Long waves, the pulsation of modern capitalism. In: HANUSCH, H; PIKA, A. Elgar companion to neo-schumpeterian economics. Cheltenham: Edward Elgar, 2007.

LUNDVALL, B-A. National innovation systems: from List to Freeman. In: HANUSCH, H; PIKA, A. Elgar companion to neo-schumpeterian economics. Cheltenham, Edward Elgar, 2007.

LUXEMBURGO, R. A acumulação de capital. São Paulo, Nova Cultural (Coleção 
Os Economistas), 1985 (1913).

MARX, K. Grundrisse. São Paulo, Boitempo; Rio de Janeiro, Ed. UFRJ, 2011 (18571858).

MARX, K. O capital: crítica da economia política. Livro I. São Paulo, Boitempo, 2013 (1867).

MARX, K. O capital: crítica da economia política. Livro III. São Paulo, Boitempo, 2017 (1894).

MAVROUDEAS, S. Social structures of accumulation, regulation approach and stages theory. In: MCDONOUGH, T; REICH, M; KOTZ, D; GONZALES-PEREZ. Growth and crises: social structure of accumulation theory and analysis. Galway, National University of Ireland, 2006. Disponível em: http://ssagalway.blogspot.com, acesso em 10/06/2010.

MCDONOUGH, T; REICH, M; KOTZ, D. Contemporary capitalism and its crises. Social structure of accumulation theory for the 21st century. Nova York, Cambridge University Press, 2010.

MCNALLY, D. From financial crisis to world-slump: accumulation, financialisation, and the global slowdown. Historical Materialism, Vol 17, No. 2, 2009.

DOI: https://doi.org/10.1163/156920609X436117.

MEDEIROS, C. Globalização, mercados e instituições segundo a perspectiva regulacionista: uma análise crítica. In: FlORI, J. L; TAVARES, M. C; RAMONET, I; CASTEL, R; HIRST, P; BOYER, R. (Orgs.). Globalização: o fato e o mito. Rio de Janeiro, Ed. UERJ, 1998.

MELLO FILHO, M. Escola francesa da regulação, escola da estrutura social de acumulação e as etapas do capitalismo. Tese (Doutorado em Economia) Universidade Federal de Minas Gerais, Cedeplar, Belo Horizonte, 2016.

MILÁ, M. Income concentration in a context of late development: an investigation of top incomes in Brazil using tax records, 1933-2013. Public Policy and Development Master Dissertation, Paris School of Economics, 2015.

NEGRI, T. L'école de la régulation face à des nouveaux problémes. In: SEBAÏ, F; VERCELLONE, C (Eds.). Ecole de la régulation et critique de la raison économique. Paris, L'Harmattan (número especial da FuturAntérieur), 1994.

NELSON, R; WINTER, S. An evolutionary theory of economic change. Londres, Harvard University Press, 1982.

PEREZ, C. Structural change and assimilation of new technologies in the economic and social systems. Futures, Vol. 15, No. 4, 1983.

DOI: https://doi.org/10.1016/0016-3287(83)90050-2

PEREZ, C. Financial bubbles, crises and the role of government in unleashing golden ages. FINNOV Discussion Paper, 2012. 
POLANYI, K. The great transformation. Nova York, Farrar \& Rinehart, 1944. POSTONE, M. Tempo, trabalho e dominação social. São Paulo, Boitempo, 2014. PRIGOGINE, I. O fim das certezas: tempo, caos e as leis da natureza. São Paulo, Ed. Unesp, 1996.

SCHNABEL, C. Union membership and density: some (not so) stylized facts and challenges. European Journal of Industrial Relations, Vol. 19, No. 3, 2013.

DOI: https://doi.org/10.1177/0959680113493373.

SEKINE, T. Uno-Riron: a Japanese contribution to Marxian political economy. Journal of Economic Literature, Vol. 13, No. 3, 1975.

DOI: http://doi.org/10.4444/34.100

UNO, K. Principles of political economy: theory of a purely capitalist society. Brighton, Harvester Press, 1980.

WALLERSTEIN, I. Time and duration: the unexcluded middle, or reflections on Braudel and Prigogine. Thesis Eleven, V. 54, N. 1, 1998.

DOI: https://doi.org/10.1177/0725513698054000007

WOLFSON, M; KOTZ, D. A reconceptualization of social structure of accumulation theory. In: MCDONOUGH, T; REICH, M; KOTZ, D. Contemporary capitalism and its crises. Social structure of accumulation theory for the 21 st century. Nova York, Cambridge University Press, 2010.

WOOD, E. The agrarian origins of capitalism. Monthly Review, Vol. 50, No. 3, 1998. DOI: https://doi.org/10.14452/MR-050-03-1998-07_2

ŽIŽEK, S. A visão em paralaxe. São Paulo, Boitempo, 2008. 